\title{
Masyarakat Melayu di Belaga: Sejarah, Perdagangan, Penempatan dan Adaptasian
}

\author{
Jayl Langub* \\ Shahren Ahmad Zaidi Adruce (Penterjemah/Translator) \\ Institut Pengajian Borneo \\ Universiti Malaysia Sarawak
}

*Corresponding author: jlangub13@gmail.com

\section{Pengenalan}

Komuniti Melayu di Belaga terdiri daripada dua perkampungan kecil: iaitu Kampung Melayu, Belaga, yang mempunyai 68 buah rumah dengan populasi sebanyak 648 penduduk; dan Kampung Hijrah, Belaga, yang mempunyai 27 buah rumah dengan populasi sebanyak 172 penduduk (Pejabat Daerah Belaga 2016). Kampung Hijrah pada mulanya merupakan sebahagian daripada Kampung Melayu Belaga sebelum berpecah menjadi dua buah kampung yang berbeza pada tahun 2014. Perubahan tersebut berlaku disebabkan kekurangan kawasan tanah bagi menampung pertambahan populasi penduduk kampung tersebut. Dengan jumlah keseluruhan populasi kedua-dua kampung sebanyak 820 penduduk, jumlah tersebut hanya mewakili sebahagian kecil daripada jumlah populasi daerah Belaga sebanyak 25,609 penduduk.

Masyarakat Melayu ini merupakan keturunan para pedagang dari Brunei dan Sumatera serta keturunan keluarga Melayu Abang6 dari Sadong, Sarawak barat dan keluarga Kedayan dari Sibuti. Sebahagian daripada pedagang tersebut mengahwini wanita tempatan dan terdapat juga pasangan yang tidak mempunyai cahaya mata mengambil anak angkat daripada keluarga tempatan. Secara keseluruhannya, golongan tersebut merupakan antara penduduk terawal di kampung Melayu Belaga.

Pelbagai kajian telah dilakukan di Daerah Belaga berkaitan komuniti Kayan (Rousseau 1974a, 1974b, 1975, 1990, 1998; Gurrerio 1988, 1992), Kajang - yang terdiri daripada masyarakat Sekapan, Kejaman, Punan Bah, dan Lahanan (de Martinoir 1974; Ida Nicolaisen 1976, 1977/78, 1983, 1984, 1986, 1997; Clayre 1971, 1972; Alexander 1989, 1990; Strickland 1986, 1988, 1989, 1995), Kenyah (Maxwell 1990; Armstrong 1991; Vom Roy 1993, Tan 1993), Penan (Needham 1953, 1954, 1965; Urquhart 1951, 1959; Johannes Nicolaisen 1976a, 1976b, 1978; Brosius 1988, 1990, 1992a, 1992b; Langub 1975, 1988, 2004), dan termasuk golongan

\footnotetext{
${ }^{6}$ Abang, dalam konteks penggunaan Melayu Sarawak merupakan gelaran bangsawan yang berasal daripada tiga ketua Melayu yang memegang gelaran datu yang tinggal di lokasi bersejarah di Lidah Tanah, lebih kurang lima belas batu melalui Sungai Sarawak daripada bandar moden Kuching (Reece n.d.). Terdapat juga di Sarawak golongan abang-abang bukan bangsawan [istilah perabangan telah lama digunakan oleh ahli sejarah seperti Craig Lockard (1973) and Sanib Said (1985)]. Terdapat beberapa keluarga abang-abang yang tinggal di Belaga, yang mendakwa bahawa mereka berasal daripada kawasan Sungai Sadong di Barat Sarawak, namun mereka kurang pasti mengenai hubungan keturunan mereka dengan keturunan abang dari Sungai Sarawak.
} 
minoriti seperti Buket (Heppel n.d.; Thambiah 1995), Sihan (Sandin 1983; Abdul Rashid 2000; Kato 2011), Seping dan Bamali (Langub 2009). Namun kajian terhadap masyarakat Melayu sangat kurang selain daripada yang disertakan di dalam isu terbitan Sarawak Gazette, penyampaian ucapan oleh para pengkaji yang mengkaji mengenai komuniti lain di Belaga, dan artikel Alan Maxwell (1999) dalam Jurnal Muzium Sarawak7.

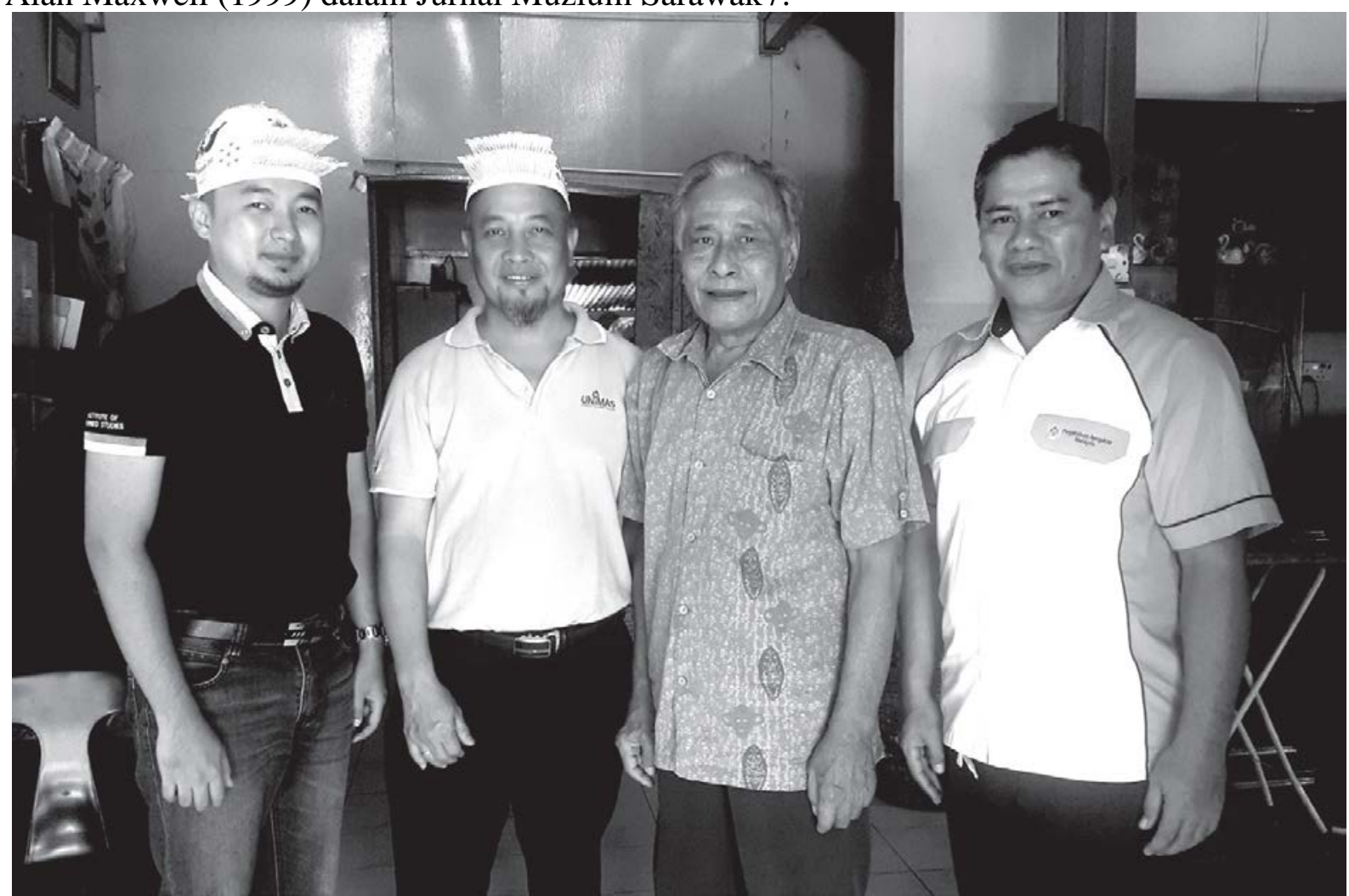

Gambar 1: Penghulu Awang Robert (Tiga dari kiri) bersama Dr Shahren, Pengarah Institut Pengajian Borneo, UNIMAS (Dua dari kiri), Abang Mohd Heikal b. Abang Othman, Pegawai Penyelidik (Dari Kiri) dan Awang Junaidi b. Awang Robert (Dari Kanan), anak kepada Penghulu Awang Robert. (Sumber gambar: Abang Mohd Heikal)

Penulisan ini bertujuan untuk mengumpul maklumat berkaitan masyarakat Melayu di Belaga melalui sumber penulisan yang sedia ada, terutamanya daripada Sarawak Gazette, dan daripada sumber temuramah bersama informan pada tahun 2017 dan 2018. Informan bagi temuramah tersebut bukan sahaja tergolong daripada bangsa Melayu sahaja, malah terdapat juga informan berbangsa Cina, Sekapan, Kejaman, Punan Bah, Kayan, Kenyah, dan masyarakat Orang Ulu yang lain di Belaga. Saya pernah menetap di Belaga ${ }^{8}$ selama empat tahun bermula dari Disember 1970 sehingga November 1974 kerana bekerja di sana sebagai Pegawai Pentadbiran Sarawak. Selama empat tahun menetap di sana, saya berpeluang untuk mengetahui serba sedikit mengenai sejarah keluarga masyarakat di sini melalui perbualan di kedai kopi, di mana masyarakat tempatan bertukar maklumat atau hanya berbual kosong sambil menghirup secawan kopi atau teh. Saya tidak berkesempatan untuk mencatat beberapa maklumat pada waktu tersebut. Namun kemudian, setelah melalui beberapa temuramah bersama informan pada tahun 2017 dan 2018, memori perbualan bersama masyarakat tempatan kembali pada ingatan saya.

\footnotetext{
${ }^{7}$ Rujukan ini, walaupun tidak berkaitan dengan komuniti Melayu, adalah disertakan di dalam penulisan ini bagi memberi gambaran kepentingan dapatan kajian daripada masyarakat yang berbeza di Belaga yang hakikatnya mungkin kurang memberi perhatian terhadap komuniti Melayu Belaga.
}

\footnotetext{
${ }^{8}$ Semasa saya menetap di sana, pekan Belaga pada ketika itu hanyalah sebuah pekan kecil yang mempunyai populasi sebanyak 447 penduduk yang terdiri daripada 200 penduduk Cina yang tinggal di dua buah bangunan kayu rumah kedai, 168 penduduk Melayu di perkampungan Melayu di hilir sungai daripada pasar, dan 78 penjawat awam (termasuk dua paderi Katolik, daripada Belanda dan Austria), dan masyarakat di situ mengenali antara satu sama lain (Rousseau 1974: 12). Daerah Belaga juga hanya mempunyai jumlah keseluruhan populasi sebanyak 9,885 penduduk.
} 
Salasilah beberapa pasangan berkahwin telah disediakan untuk saya, dan tujuh daripadanya dibentangkan dalam penulisan ini bagi menunjukkan wujudnya hubungan kekeluargaan dalam kalangan komuniti di Brunei, Sumatera, Sadong, Sibuti dan beberapa komuniti asli yang terdapat di daerah Belaga.

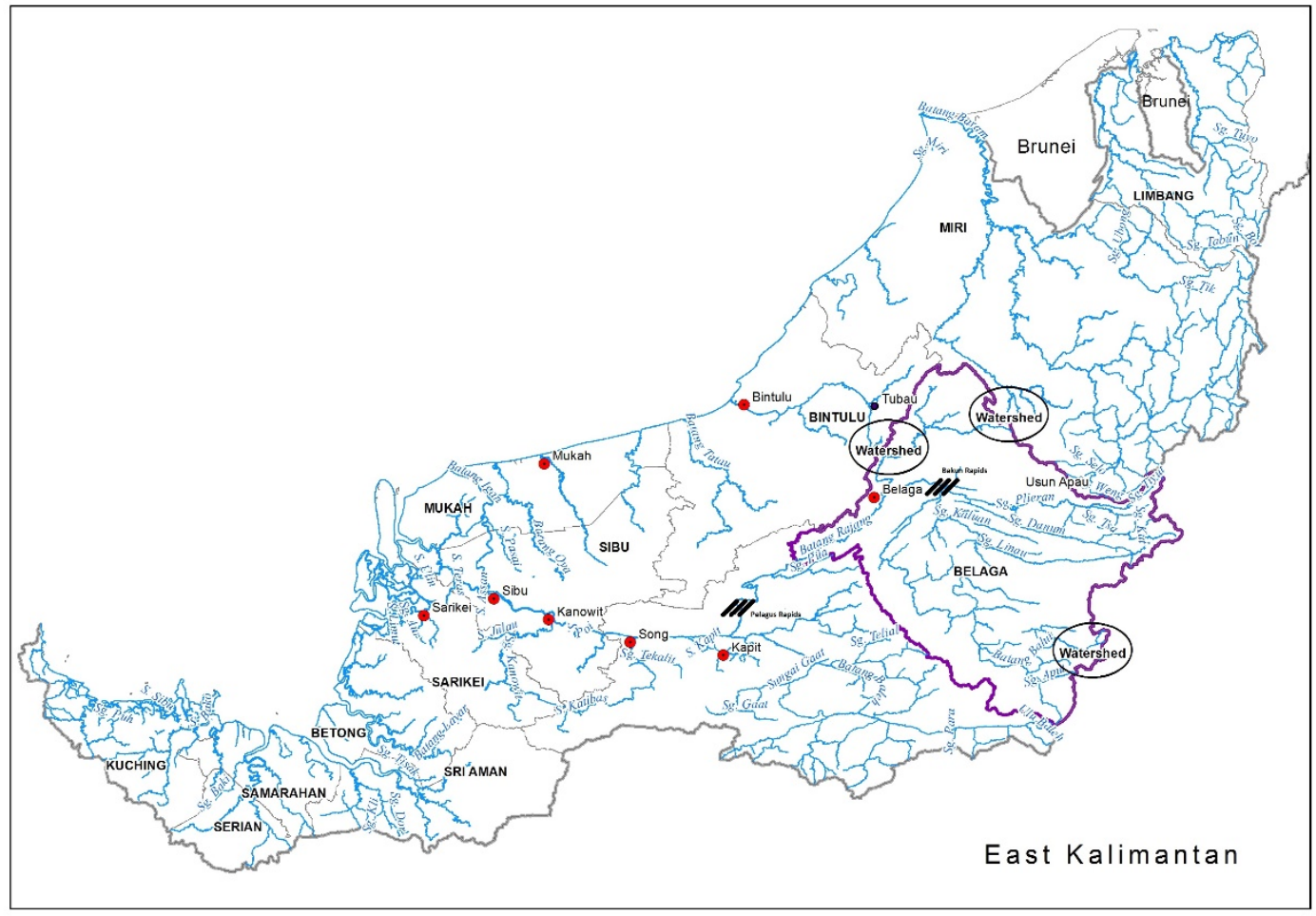

Peta Lembah Rejang (Langub 2016: 122)

\section{Daerah Belaga dan Penduduknya}

Daerah Belaga terletak di hulu Rejang dan berkongsi sempadan antarabangsa dengan Kalimantan Utara yang merupakan sebahagian daripada wilayah Indonesia (Rujuk Peta Lembah Rejang). Ia mempunyai keluasan 19,403.2 kilometer persegi dan populasi sebanyak 25,609 penduduk (Pejabat Daerah Belaga 2016: 9). Belaga merupakan daerah yang berbukitbukau dan bergunung-ganang. Di bahagian barat, Belaga berhubung dengan daerah Kapit dan daerah-daerah lain disepanjang bahagian hilir Rejang melalui Sungai Rejang. Di bahagian timur, Belaga berkongsi sempadan dengan Apo Kayan di Kalimantan Utara wilayah Indonesia. Terdapat dua laluan yang menghubungkan Belaga dengan Apo Kayan: pertama, melalui sungai Aput, yang merupakan anak sungai di hulu sungai Balui; kedua, melalui Sungai Kajang, yang merupakan anak Sungai Linau, di mana ia juga merupakan sebahagian daripada hulu Sungai Balui (Rousseau 1974a: 1990).

Di bahagian utara, Belaga berjiran dengan daerah Baram, Bintulu, dan Tatau. Sekitar tahun 1800, sudah terdapat beberapa laluan yang menghubungkan Belaga dan Baram. Laluan tersebut ditemui sepanjang tempat tadahan air antara Tinjar dan anak-anak sungainya, Dapoi, Nibong dan Lobang di Baram dan Belaga, anak sungainya, Koyan serta Seping, Menavan, hulu anak Sungai Luar yang merupakan anak sungai kepada Plieran di bahagian Belaga (Needham 1953: 52-87; Arnold 1956, 1959; Metcalf 1976, 2002, 2010; Langub dan Ishikawa 2017). Laluan tersebut pada asalnya digunakan oleh komuniti di Usun Apau, Berawan, Sebop, Lirong, Penan dan pelbagai suku kaum Kenyah yang berhijrah ke Tinjar dan Baram. Tidak lama 
kemudian, laluan tersebut mula digunakan sebagai laluan untuk menziarahi saudara dari keduadua belah bahagian kawasan tempat tadahan air.

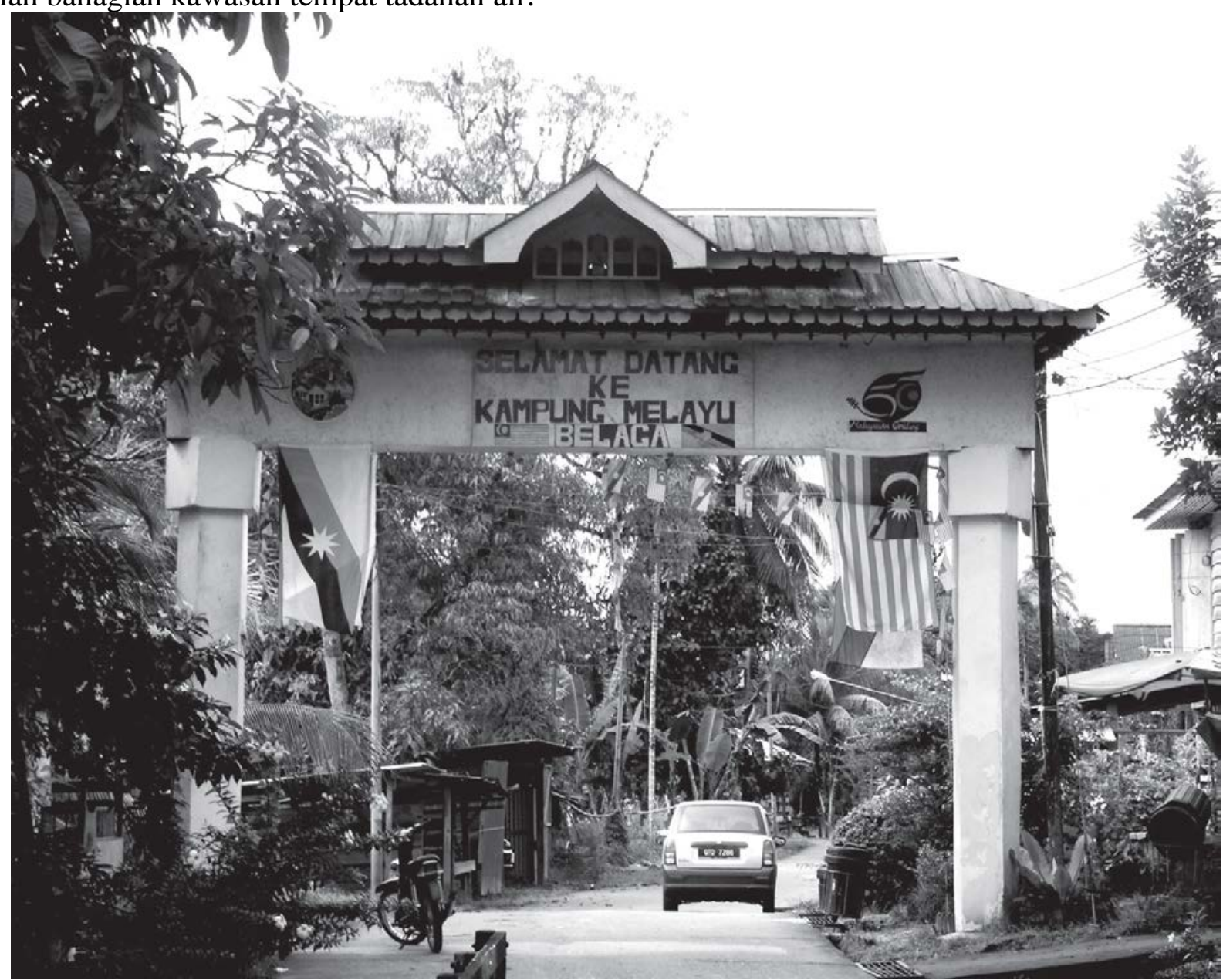

Gambar 2: Pintu Gerbang Kampung Melayu Belaga. (Sumber gambar: K. Egay)

Tempat tadahan air Sepakau-Tubau merupakan laluan perdagangan terpenting yang menghubungkan Belaga dengan kawasan pantai Bintulu dan kawasan-kawasan yang lain. Laluan tersebut juga digunakan oleh pedagang Melayu Brunei dalam urusan perdagangan dengan penduduk di Belaga dan Balui di kawasan hulu Rejang (de Crespigny 1881, 1882; Gueritz 1882; Owen 1903; Langub dan Ishikawa 2017). Komuniti Punan Bah juga turut menggunakan laluan tersebut untuk berhijrah ke Kemena dan menubuhkan penempatan di Pandan (Nicolaisen 1976, 1983).

Belaga juga dihubungkan dengan daerah Tatau di bahagian utara melalui kawasan tadahan air Sematai-Putih. Sebagai contoh, seseorang boleh menggunakan perahu dari Sungai Bah ke Sematai, mendaki bukit sehingga ke puncak tempat tadahan air Sematai-Putih, kemudian menuruni bukit Putih ke Kakus di daerah Tatau. Antara komuniti terawal yang menggunakan laluan tersebut ialah Punan Bah yang diketuai oleh Tageang. Tageang berkahwin dengan Siki, anak perempuan ketua kawasan Tatau. Beliau kemudiannya telah mencipta nama bagi dirinya sebagai orang penting dalam kalangan masyarakat. Sebelum adanya jalan pembalakan yang menghubungkan Tatau ke Belaga pada tahun 1990-an, laluan tempat tadahan air Sematai-Putih merupakan laluan yang amat penting bagi masyarakat Punan Bah di keduadua bahagian Tatau dan Belaga untuk menziarahi antara satu sama lain. 
Hugh Brooke Low berkemungkinan adalah pengkaji Eropah pertama yang mengiktiraf dan merekod populasi kepelbagaian etnik di Belaga, yang telah diterbitkan di dalam buku harian beliau di Sarawak Gazette pada tahun 1882 dan 1884 (Low 1882a-e, 1884a-e). Komuniti Sekapan (pop. 1,085), Kejaman (pop. 962), Lahanan (pop. 798), dan Punan Bah (pop. 1, 077) merupakan antara komuniti yang pertama menduduki daerah Belaga (de Martinoir 1974; Clayre 1971, 1972; Nicolaisen 1976, 1977/78, 1983, 1986, 1997; Strickland 1986, 1988, 1989, 1995 Bahagian I dan II). Keempat-empat komuniti tersebut mempunyai banyak persamaan dari segi bahasa dan budaya. Bagi membezakan komuniti ini dengan komuniti utama di Belaga, iaitu Kayan dan Kenyah, adalah melalui makanan ruji komuniti tersebut. Sago merupakan makanan ruji bagi komuniti Sekapan, Kejaman, Lahanan dan Punan Bah manakala bagi komuniti Kayan dan Kenyah, makanan ruji mereka ialah nasi. Disebabkan komuniti ini mempunyai banyak persamaan antara satu sama lain, maka mereka menganggap komuniti mereka merupakan satu etnik yang sama dipanggil Kajang.

Istilah Kajang telah diperkenalkan dalam istilah kesusasteraan oleh Leach (1950: 63 perenggan 271), namun Harrison menidakkan kewujudan istilah asli tersebut (dipetik dari Rousseau 1990: 60). Walaubagaimanapun, de Martinoir menyatakan bahawa komuniti yang menggelar diri mereka sebagai Kajang mendefinisikan diri mereka sebagai "kumpulan yang membangkang komuniti Kayan”, yang merupakan sekumpulan penghijrah yang mendominasi politik di hulu Rejang pada dua abad yang lalu. Bersetuju dengan pendapat de Martinoir, Rousseau (1974b: 39) menyatakan bahawa pembentukan kategori 'Kajang' merupakan satu perubahan yang berlaku disebabkan oleh peristiwa bersejarah yang berlaku pada ketika dulu, merujuk kepada dominasi politik oleh etnik Kayan di hulu Rejang. Melihat daripada perspektif komuniti Punan Bah, laporan Nicolaisen (1976/1977: 194) menunjukkan bahawa keempatempat komuniti, iaitu komuniti Sekapan, Kejaman, Lahanan dan Punan Bah menganggap diri mereka sebagai Kajeang lan, atau "Kajang asli", manakala etnik minoriti seperti Seping, Bamali, Sihan dan Buket yang meletakkan diri mereka dalam kalangan kumpulan yang membangkang etnik Kayan, dianggap sebagai komuniti yang dipinggirkan. Sebagai satu kumpulan, golongan yang dikenali sebagai Kajang berkongsi persamaan linguistik dan kebudayaan dengan masyarakat Melanau di pesisiran pantai dan komuniti yang berkaitan seperti Tanjong dan Kanowit (Clayre 1972: 47).

Dengan catatan populasi semasa sebanyak 7,104 penduduk, masyarakat Kayan merupakan kumpulan etnik kedua terbesar di Belaga. Masyarakat ini berasal dari Apo Kayan di Kalimantan Utara, sekitar dua abad yang lalu. Mereka berpindah ke Sungai Kayan, melalui tempat tadahan air di hulu sungai Balui dan Linau (Rousseau 1990: 331-334). Sebahagian kumpulan lagi datang dari Mahakam, yang merupakan sebuah kawasan di Kalimantan. Mereka datang ke Belaga menggunakan laluan dari Baleh dan menyusuri Rejang dan seterusnya menetap di Sungai Pilah. Disebabkan oleh perkembangan masyarakat Iban di kawasan tersebut, masyarakat Kayan terpaksa berpindah dari Rejang ke Belaga pada sekitar abad ke-20. Masyarakat Kayan pada masa kini merupakan komuniti yang paling dominan dan menguasai kumpulan politik paling penting di daerah Belaga.

Masyarakat Kenyah merupakan etnik terbesar di Belaga dengan populasi sebanyak 9,073 penduduk. Etnik ini merangkumi beberapa suku kaum yang mempunyai persamaan dari segi dialek pertuturan. Pada akhir tahun 1800, Hugh Brooke Low telah melawat Belaga dan berjaya mengenal pasti beberapa dialek. Antara yang dapat dikenal pasti ialah dialek Badeng, Lepu Aga, Lepu Anan, Lepu Jingan, Lepu Linau, Lepu Sawa, Lepu Tau, Lepu Tepu, Long Bangan, Uma Jalan, Uma Kelap, Uma Pawa, Uma Sambop, dan Uma Time. Lokasi mereka telah dikenal pasti di kawasan Usun Apau dan Sungai Penyuan, dan anak sungai Belaga (catatan 
harian Brooke Low 1880a-e, 1884a-e; de Crespigny 1881a-c, 1882; Gueritz 1881a-c, 1882). Masyarakat Kenyah Uma Kulit dan Uma Bakah merupakan kumpulan yang tidak disenaraikan dalam catatan harian Brooke Low kerana mereka datang ke Belaga pada tahun 1950, dan juga tambahan kepada kumpulan Badeng pada tahun 1960 (Maxwell 1990; Armstrong 1991; Roy 1993; Tan 1993).

Kebanyakan suku kaum yang dinyatakan oleh Brooke Low berkemungkinan berhijrah ke Tinjar dan Sungai Baram atau bergabung menjadi satu suku kaum yang besar (Arnold 1956, 1959; Metcalf 2002). Pada hari ini, masyarakat Kenyah di Belaga terdiri daripada suku kaum Badeng, Long Bangan, Uma Bakah, Uma Kelap, Uma Kulit, Uma Pawa dan Uma Sambop. Brooke Low turut menyatakan mengenai kumpulan minoriti seperti Buket, yang juga dikenali sebagai Ukit, Lirong, Sebop, Seping dan Sihan (Low 1882a-e). Kumpulan lain yang tidak dinyatakan dalam catatan beliau ialah Bamali, yang sering kali disenaraikan di bawah kumpulan Seping (lihat de Crespigny 1881a-c, 1882; Gueritz 1882a-c; Needham, 1953; Rousseau 1990; Arnold 1956, 1959; Metcalf 1989, 2002, 2010; Gockel 1974; Seling Sawing 1974).

Kumpulan Buket dan Sihan dahulunya menetap di Baleh, namun disebabkan perluasan kawasan masyarakat Iban di Rejang pada tahun 1850 (lihat catatan harian Brooke Low 1882ae), suku kaum Sihan mengambil perlindungan dalam kalangan penduduk Kajang di Sungai Menamang, manakala suku kaum Buket berlindung dalam kalangan penduduk Kayan di hulu Balui. Pada hari ini, mereka merupakan 207 penduduk Sihan dan 518 penduduk Buket di Belaga.

Suku kaum Lirong, Sebop, Seping dan Bamali merupakan antara penduduk terawal menduduki hulu Rejang yang terletak di kawasan Usun Apau. Suku kaum Lirong dan Sebop berpindah keluar dari kawasan Usun Apau mengikut peringkat, sebahagian berpindah pada awal 1800, sebahagian lagi berpindah pada pertengahan dan akhir tahun 1800 ke Sungai Tinjar di daerah Baram (Metcalf, 2002, 2010; Arnold 1956, 1959; Gockel 1974; Seling Sawing 1974). Pada sekitar tahun yang sama, suku kaum Seping dan Bamali berpindah dari Sungai Seping ke Sungai Belaga di mana mereka kekal di situ hingga ke hari ini (Langub 2009). Selain daripada beberapa buah keluarga, suku kaum Bamali sudah pupus kerana kebanyakan mereka bergabung dengan suku kaum Seping, Kejaman, dan Sekapan melalui perkahwinan campur. Jumlah populasi suku kaum Seping dan Bamali ialah 470 penduduk.

Brooke Low juga ada menyatakan mengenai suku kaum Penan yang sentiasa berpindahrandah, walaupun beliau tidak melawat suku kaum ini di kawasan Usun Apau dan Sungai Linau. Jumlah populasi masyarakat Penan pada hari ini sebanyak 2,820 penduduk. Masyarakat Penan dikenali sebagai masyarakat yang sering berpindah-randah, mereka juga telah membina penempatan di kebanyakan kawasan pedalaman di daerah tersebut, seperti di Linau, Danum, Plieran, Seping, dan sungai Belaga (Needham 1953; Brosius 1986, 1988, 1992; Langub 1975, 1988, 2004).

Masyarakat Punan Vuhang (Ellis 1972; Chan 2007) juga merupakan masyarakat yang berpindah-randah, namun terdapat perbezaan bahasa daripada masyarakat Penan. Mereka telah mendirikan dua buah penempatan: Long Lidem, di Sungai Kajang yang berdekatan dengan sempadan Sarawak-Kalimantan Utara, dengan jumlah penduduk sebanyak 75 orang; dan Long Unai di hulu Balui yang juga berdekatan dengan sempadan Sarawak-Kalimantan Utara, dengan jumlah penduduk sebanyak 282 orang. 
Suku kaum Tanjong dan Lisum mendiami sebuah rumah panjang di Long Pawah, di bawah rumah panjang suku kaum Sekapan di Long Dungan. Mereka membina penempatan tersebut pada awal tahun 1970. Rumah panjang mereka didiami oleh 20 keluarga, terbahagi kepada 16 suku kaum Tanjong dan empat suku kaum Lisum. Suku kaum Tanjong mempunyai persamaan bahasa dan budaya dengan komuniti Kajang dari Belaga dan komuniti Melanau di pesisir pantai. Bagi suku kaum Lisum, mereka dikenali sebagai komuniti berpindah-randah yang sering berkeliaran di hulu sungai Kayan dan Balui.

Ketika Brooke Low melawat Belaga pada tahun 1883 bersama beberapa orang pekerja dari Rejang untuk membina kubu di Belaga, beliau melaporkan kewujudan beberapa orang pedagang Cina (lihat catatan harian Brooke Low 1884a-e). Pada tahun 1893, Residen Bamfylde (1893) melaporkan bahawa terdapat 15 buah kedai akan dibina, 10 buah oleh masyarakat Cina dan lima buah oleh masyarakat Melayu. Pada hari ini, terdapat 400 orang berbangsa Cina di Belaga. Seperti kebanyakan masyarakat Cina yang terdapat di Asia Tenggara, komuniti ini mendominasi keseluruhan perdagangan dan perniagaan di bandar tersebut.

Para pedagang berbangsa Melayu sudah lama bertapak di hulu Rejang sebelum datangnya pemerintahan Brooke pada 1861. Seperti yang telah dinyatakan pada awal penulisan ini, komuniti Melayu ini kebanyakannya datang dari Brunei dan sebahagiannya dari Sumatera. Perenggan seterusnya menerangkan dengan lebih terperinci mengenai kedatangan dan penubuhan penempatan masyarakat Melayu di Belaga serta bagaimana masyarakat ini menjadi sebahagian daripada komuniti di kawasan hulu Rejang.

\section{Perdagangan di pedalaman}

Sebagai sebuah negara yang merdeka, Brunei mempunyai hubungan perdagangan antarabangsa yang mengeksport hasil produk hutan. Disebabkan kebanyakan hasil hutan tersebut diperoleh daripada lembangan sungai Baram dan Rejang, pedagang Melayu Brunei melakukan ekspedisi secara berkala ke kawasan pedalaman tersebut. Metcalf (2010: 138) dalam penulisannya menyatakan:

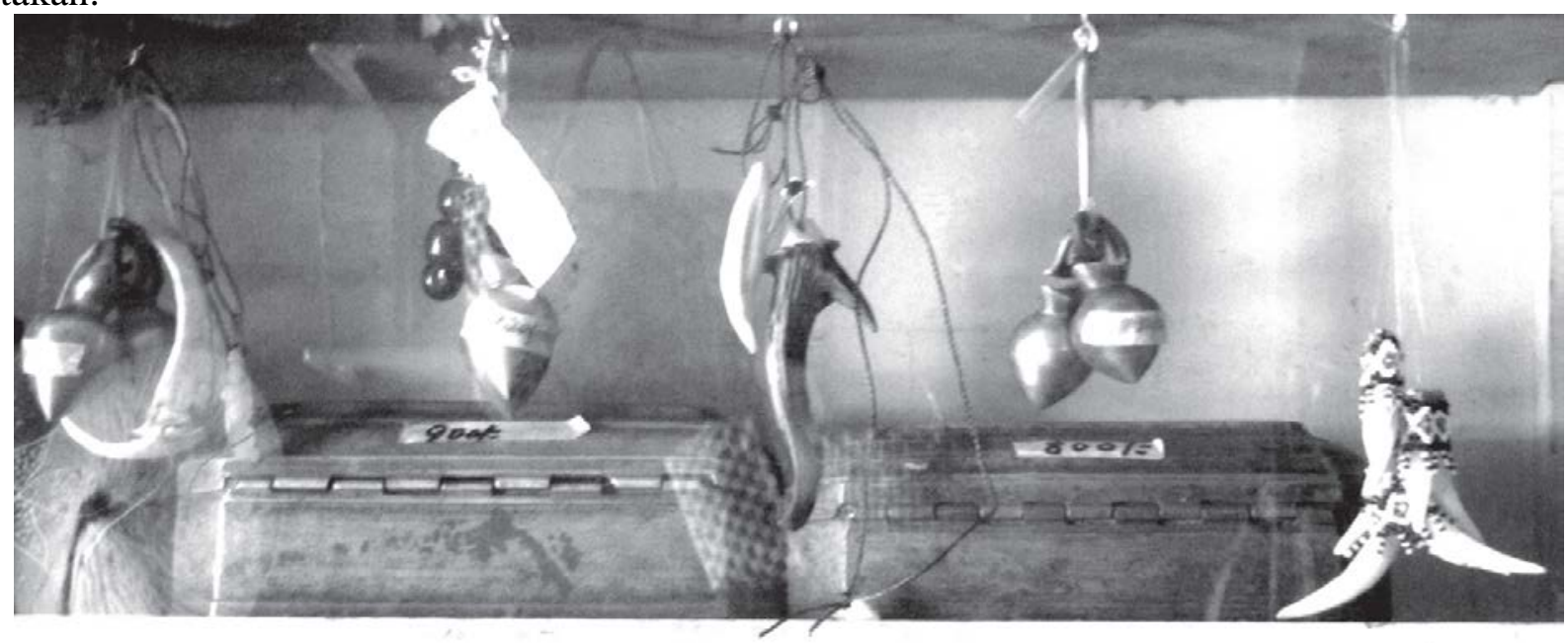

Gambar 3: Peti Tembaga, merupakan salah satu alatan dagang daripada pedagang Melayu Brunei, didapati diruang pameran untuk jualan dikedai antik di pasar Belaga. (Sumber gambar: J. Langub) 


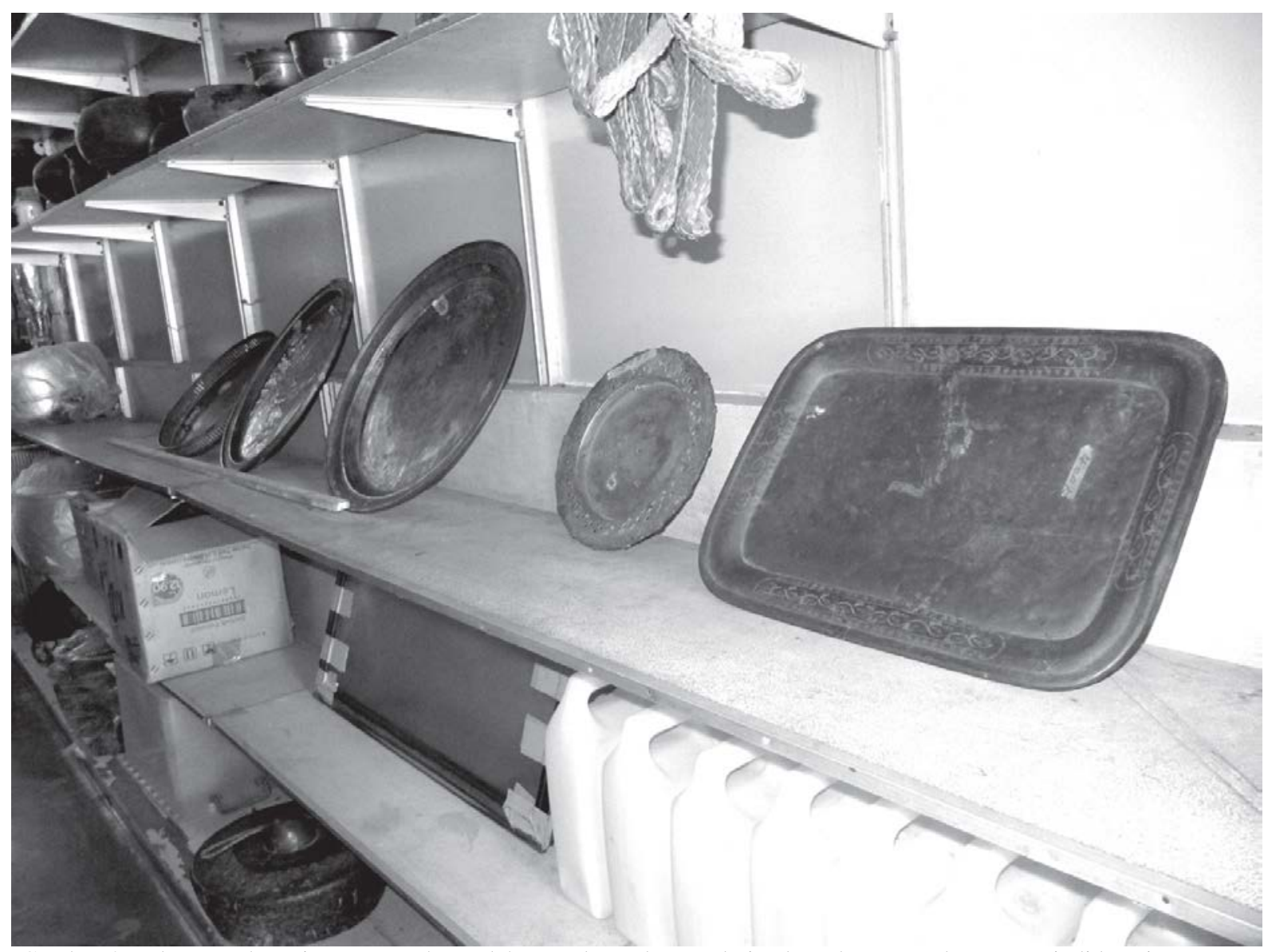

Gambar 4: Talam Tembaga,juga merupakan salah satu alatan dagang daripada pedagang Melayu Brunei, didapati diruang pameran untuk jualan dikedai antik di pasar Belaga. (Sumber gambar: J. Langub)

Mengenai perdagangan di pedalaman Brunei, terdapat dua perkara yang sangat menonjol: pertama, aktiviti pengeksportan Brunei sejumlah besar terdiri daripada hasil hutan; dan kedua, status tinggi komuniti di rumah panjang di hulu sungai dapat dilihat berdasarkan barang-barang yang diimport dari Brunei. Bukti ini sudah cukup untuk menunjukkan perkaitan rapat antara sejarah masyarakat di pesisir pantai dan masyarakat di pedalaman.

Di Rejang, bahagian hulu lembangan sungai merupakan kawasan yang sangat bernilai. Kawasan tersebut kaya dengan sumber hutan. Disebabkan kekayaannya, de Crespigny (1991b: 7) berkata demikian:

Kapur barus dan getah yang berkualiti boleh didapati dan terletak di daerah yang lebih jauh di antara Rejang dan kawasan Bulongan. Sumber tersebut masih belum diterokai secara keseluruhannya. Hutan tersebut juga mempunyai banyak sumber rotan... sarang burung yang boleh dimakan juga dikatakan wujud, namun saya tidak berkesempatan kerana lawatan saya ketika itu jauh dari mana-mana kawasan bukit batu kapur. Kristalkristal kecil yang kelihatan seperti rubi juga banyak didapati di Long Urun dan juga Long Latai di Sepeng.

Pedagang Melayu Brunei menuju ke Belaga dan Balui kawasan hulu Rejang melalui penempatan pesisir pantai di Bintulu. Dari situ, mereka menggunakan perahu ke Kemena sehingga ke pertemuan antara Tubau dan Jelalong. Di pertemuan tersebut, mereka meneruskan perjalanan ke Tubau di tempat tadahan air Tubau-Sepakau dan melalui anak sungai Sepakau ke sungai Belaga. Dari sungai Belaga, mereka mendayung sehingga ke pertemuan Balui yang membentuk sungai Rejang yang mengalir ke utara ke arah Laut China Selatan. 
Sebelum lembangan sungai Bintulu dan Rejang menjadi sebahagian daripada pengaruh Brooke pada 1861, Tubau sudah menjadi satu pusat perdagangan yang penting. Masyarakat pedalaman di Sungai Belaga dan Balui mengembara ke Sungai Belaga ke anak Sungai Sepakau, mendaki tempat tadahan air Sepakau-Tubau, menghilir Sungai Tubau sehingga ke pertemuan antara Jelalong untuk ke pusat perdagangan Tubau. Pusat perdagangan yang lebih kecil dikenali sebagai Kabulu, juga telah ditubuhkan di pertemuan antara Jelalong dan Kabulu. ${ }^{9}$ Masyarakat Penan di sungai Suai, Sebop, Lirong serta masyarakat Penan di hulu Tinjar datang ke Kabulu untuk berdagang dengan pedagang Melayu Brunei.

Kesultanan Brunei ingin menggalakkan perdagangan antara masyarakat pedalaman di Sungai Belaga dan Balui, maka, sebuah pusat perdagangan yang kecil telah ditubuhkan di antara kedua-dua kawasan tersebut. Seperti yang akan diterangkan dengan lebih lanjut, Brooke Low telah membina Kubu Vyner dan sebuah pasar tetap pada tahun 1883. Oleh itu, pembangunan tersebutlah yang mewujudkan bandar Belaga pada masa kini. Walaubagaimanapun, pada mulanya pusat perdagangan tersebut diduduki oleh pedagang Melayu daripada Brunei (Nicolaisen 1976: 65; Yao 1987: 18-19). Sebahagian daripada pedagang tersebut berkahwin dengan wanita tempatan, masih menetap di Belaga, dan membuka laluan kepada perkampungan yang terdiri daripada komuniti Melayu Brunei. Pedagang Brunei ini juga, seperti yang dikatakan oleh cerita lisan masyarakat Punan Bah, bagi menjamin keselamatan mereka, mereka berhijrah dari satu suku kaum ke satu suku kaum yang lain walaupun mereka mempunyai perlindungan daripada Sultan Brunei (Nicolaisen 1983:197).

Perdagangan antara pedagang Melayu Brunei dan masyarakat pedalaman Sungai Belaga dan Balui berterusan walaupun ketika Bintulu dan lembangan Rejang berada di bawah pemerintahan Brooke pada tahun 1861. Malah, pegawai Brooke sedaya upaya menjaga keselamatan dan kebajikan para pedagang. Sebagai contoh, pada Oktober 1881, dalam isu Sarawak Gazette C.A.C. de Crespigny (1881b: 7), Residen Mukah telah mengeluarkan perintah kepada penghutang Sepeng seperti yang tertera:

Saya bercakap kepada Tama Laang dan Tama Sulalang. Saya memaklumkan mengenai rungutan para pedagang Brunei terhadap suku kaum Sepeng yang lewat membayar hutang mereka. Saya telah menunjukkan contoh orang-orang Kenniah [Kenyah] yang tidak berhutang tetapi dapat membeli barang keperluan menggunakan wang yang ada atau hasil barangan dan saya meminta kepada mereka untuk menjaga keselamatan semua pedagang serta pendatang yang datang ke Belaga pada masa hadapan.

Pegawai-pegawai di bawah pimpinan Brooke bukan sahaja bimbang mengenai keselamatan para pedagang terutamanya pedagang dari Brunei malah mereka juga mendapati masalah dalam meyakinkan penduduk tempatan terhadap kelebihan melibatkan diri dalam aktiviti perdagangan. Misalnya, de Crespigny pernah menyebut bahawa terdapat seorang suku kaum Sebop Lirong yang gigih, maka, beliau berharap dia dapat membantu menggalakkan penduduk-penduduk yang lain untuk mengambil peluang melibatkan diri dalam aktiviti tersebut.

Boling seperti yang disebut diatas merupakan seorang Lirong dari Pliran dan adik kepada Ketua Pliran iaitu Tinjan. Dia telah berkahwin di Peninan [Penyuan] dan merupakan seorang pedagang yang gigih. Saya berharap dengan bantuan beliau sumber-sumber asli yang kaya dari Daerah Ba Sep[i]ng dan Balui Peh [Belepeh] akan dibuka tidak lama lagi serta penduduk yang mendiami kawasan berkenaan akan sedar terhadap kelebihan yang tersedia

\footnotetext{
${ }^{9}$ Temubual bersama Ogos Sugun, ketua masyarakat Penan di Jambatan Suai, Daerah Miri, 21 Ogos 2012.
} 
untuk mereka dengan menjaga keselamatan pedagang-pedagang seperti yang dilakukan di Belaga (de Crespigny 1881b: 6).

Terdapat dua kampung di Brunei memainkan peranan yang penting dalam penubuhan komuniti Melayu di Belaga: Kampung Burong Pingai dan Kampung Tamui. Walaubagaimanapun, Kampung Burong Pingai merupakan kampung yang lebih penting kerana "pedagang-pedagang dari kampung berkenaan terkenal di sepanjang pantai timur laut Borneo pada abad ke-19 sebagai Nakoda [kapten kapal, terutamanya dari kapal dagang]” (St John 1862 II: 254). Pada tahun 1881, de Crespigny iaitu Residen di Mukah, melaporkan bahawa terdapat sekumpulan penduduk Burong Pingai menetap di kawasan sungai Penyuan yang merupakan cabang dari sungai Belaga, 20 kilometer dari anak sungai Sepakau yang menghubungkan Bintulu dan Tubau ke Belaga dan kawasan Balui di hulu sungai Rejang (de Crespigny1881a: 41):

Terdapat 70 orang Brunei (Burong Pingai) di Pen[y]uan pada masa berkenaan. 30 daripada mereka adalah pedagang manakala 40 adalah pembantu. Mereka ini bukanlah orang yang sama daripada tiga tahun yang lepas kerana orang yang pernah menetap di sana telah mengumpul keuntungan yang besar dan telah pulang ke Brunei dan seterusnya menetap di Baram. Transit adalah lebih mudah daripada dua tahun yang lepas untuk orang $\mathrm{Ka}[\mathrm{y}] \mathrm{an}$ di kawasan berkenaan dan orang Ken[y]ah di kawasan yang lain bagi mengangkut barangan merentasi bukit (satu hari berjalan), untuk memperoleh beberapa balang garam bagi setiap perjalanan mengangkut barang. Selain itu, tidak ada keperluan lagi untuk mengangkut beras dan barang keperluan yang lain kerana Jalong, Ingan dan orang-orang Kenyah yang lain merupakan petani yang bagus sehingga terdapat bekalan beras yang banyak serta murah di Belaga sepanjang tahun.

Pada waktu berkenaan, kawasan Belaga dan Balui dari hulu Rejang ditadbir dari Mukah iaitu kawasan pentadbiran Residen dari lembah Rejang. (Residen berkenaan berpusat di Bintulu namun apabila keadaan memerlukan, beliau juga melawat kawasan Belaga dan Balui). Dikatakan adalah lebih mudah untuk mentadbir hulu Rejang dari Mukah melalui Bintulu, naik ke Kemena dan Tubau ke anak sungai Sepakau serta ke sungai Belaga dan seterusnya ke hulu Rejang daripada melalui perjalanan merentasi muara sungai Rejang, melalui bahagian hulu sungai merentasi jeram Pelagus yang berbahaya. Pada sekitar tahun 1882, kawasan hulu Rejang yang sebahagian besarnya terdiri daripada lembah Balui dan Belaga ditadbir dari Sibu seperti yang dibincangkan.

Pada February 1881, George Gueritz iaitu Residen yang berpusat di Bintulu, telah melawat Belaga dan melaporkan bahawa "dari Belaga saya mempunyai khabar yang cukup bagus mengenai aktiviti perdagangan disana. Pedagang dari Brunei memiliki bazar yang tersendiri...” (Gueritz 1881a: 12). Dalam Sarawak Gazette isu Mac 1881, Gueritz (1881b: 49) menyatakan bahawa "saya bercadang untuk melawat Belaga dalam tempoh bulan hadapan untuk mengawasi kerja pelaksanaan balai polis di kawasan muara sungai Penyuan setelah menerima kebenaran daripada Residen Bahagian.” Sepanjang lawatan Gueritz pada April 1881, beliau telah melaporkan bahawa terdapat banyak batang pokok yang terapung di bahagian hulu Sungai Tubau sehingga ke kawasan daratan di Long Unai yang menyekat aliran sungai (Gueritz 1881c: 49). Walaubagaimanapun, dari kawasan Long Unai, orang Kenyah telah membina "jalan balak yang agak baik” melalui rabung yang memisahkan kawasan tadahan air Tubau dan Belaga yang menjadi laluan perjalanan Gueritz dan pengikutnya sepanjang empat jam untuk sampai ke kawasan daratan di Sepakau (Gueritz 1881c: 49). 
Pada perjalanan yang berikutnya, Gueritz melaporkan kewujudan penempatan 106 buah pintu dan 530 orang Kenyah yang tinggal di bahagian muara Penyuan dibawah pimpinan Aban Jalong (Gueritz 1881c: 49). Oleh itu, Saya terkejut kerana perubahan yang besar telah berlaku di daerah itu sejak lawatan saya lebih daripada dua tahun yang lepas. Pada masa itu, tiada pedagang yang menyelusuri sungai berkenaan serta orang Seping, Ba Mal[i] dan 200 ke 300 orang Kenyah yang baharu sahaja mendiami kawasan tersebut berada di dalam keadaan yang sangat daif malah kebanyakan mereka di ambang maut disebabkan oleh kelaparan. Kini, keadaan amatlah berbeza. Orang Kenyah yang merupakan petani yang tekun memiliki bekalan beras yang banyak serta dapat dikongsi bukan sahaja untuk keperluan diri sendiri malah untuk kebaikan Ba Mali, Seping dan Sebop. Terdapat lebih kurang 50 pedagang kebanyakannya orang Brunei yang telah menjual barangan yang bernilai sebanyak \$15,000 sepanjang 12 bulan yang lepas serta orang Cina di Tubau dan Bintulu berkemungkinan telah menjual barangan yang bernilai $\$ 10,000$ atau lebih. Ketua-ketua orang Kenyah telah menunjukkan kegembiraan mereka atas lawatan saya dan meyakinkan saya bahawa mereka dan pengikutnya berasa puas hati dengan keadaan semasa dimana mereka dapat memperoleh bukan sahaja keperluan hidup malah pelbagai kemewahan yang mereka tidak pernah impikan. Para pedagang telah menerima tawaran sejumlah wang untuk membersihkan sungai Tubau daripada batang-batang kayu. Saya berharap dapat mendorong orang-orang Kayan dan Penan untuk melaksanakan tugasan berkenaan. Dengan bersihnya sungai Tubau, perjalanan ke Belaga dari Bintulu dapat dilakukan dalam masa empat hari mahupun tiga hari jika ada kecemasan manakala perjalanan pulang akan mengambil tempoh dua hari sahaja.

Salah satu aspek menarik dari laporan Gueritz dalam Sarawak Gazette pada bulan April 1881 adalah banci penduduk untuk penempatan di Penyuan (Gueritz 1881c: 49). Daripada banci penduduk berkenaan: Kenyah 574 orang, Seping 122 orang, Ba Mali 81 orang, Sebop 35 orang dan pedagang kebanyakannya orang Brunei, 50 orang, memberi jumlah sebanyak 862 orang. Dalam laporan beliau dalam Sarawak Gazette pada bulan Mac, Gueritz (1881b: 49) melaporkan bahawa:

Tidak dapat dinafikan bahawa Belaga tidak lama lagi akan menjadi pusat perdagangan yang penting dalam negara, Belaga merupakan pusat perdagangan bagi populasi besar yang mendiami kawasan hulu sungai Balungan, Bal[u]i dan Tinjar.

Terdapat keperluan untuk membaik pulih jalan perdagangan apabila kadar perdagangan diantara penduduk di Belaga meningkat. Dalam Sarawak Gazette isu bulan Ogos 1881, de Crespigny melaporkan bahawa pedagang Cina telah menggunakan sejumlah wang yang bernilai \$65 untuk membaiki jalan ke Belaga manakala Akam Batu; individu yang berbangsa Kayan telah bersetuju untuk membersihkan batang-batang kayu dan sampah-sarap dari sungai Tubau untuk \$46 (de Crespigny 1881b: 65-66).

\section{Ketua tempatan dan Sultan}

Tokoh tempatan yang menarik dengan nama Sagiang, pada zaman kehidupannya yang tidak menentu, membantu menghubungkan istana dan pedagang Brunei kepada pemimpin tempatan di Belaga. Mengikut naratif lisan Punan Bah, Sagiang ialah seorang bangsawan Punan Bah yang mengetuai pengikutnya untuk mencari penempatan di Pandan di Sungai Kemena yang dahulunya terletak di daerah Bintulu. Keluarganya membantu dia untuk berkahwin dengan gadis Kayan keturunan bangsawan (Leach 1950: 77). Bagaimanapun, dia jatuh cinta dengan seorang gadis kelas biasa yang menimbulkan kemarahan suku kaum Kayan sehingga keluarganya berpendapat adalah lebih baik agar Sagiang pergi meninggalkan kawasan Rejang 
(Nicolaisen 1976: 85). Pertama, dia melawat abangnya, Tigeang ${ }^{10}$ di Tatau; maka dia "menghabiskan 10 tahun di Brunei di mana dia menaikkan pangkatnya di mahkamah, memperisterikan wanita Melayu dan menjadi seorang Muslim" (Nicolaisen 1976: 85). Selepas bertahun-tahun di Brunei, beliau telah dihantar ke Tubau, mungkin untuk memastikan perdagangan antara pedagang Brunei dan penduduk tempatan, kemudian turun Kemena ke Labang, dan akhirnya ke Pandan untuk menubuhkan penempatan dengan para pengikutnya, dan menetap secara kekal. Seperti abangnya, Tigeang yang mengahwini Siki, anak perempuan seorang ketua Tatau, dan menjadi tokoh yang dihormati di Tatau, Sagiang pula berkahwin dengan Nyaladi, anak perempuan ketua Vaie Segan yang merupakan pemimpin yang dihormati di lembah Kemena.

Kesultanan Brunei dengan niat ingin mempromosikan perdagangan dengan orang pedalaman dan berminat bertemu dengan para pemimpin kawasan pedalaman. Melalui Sagiang, beberapa pemimpin dari Belaga telah diundang ke Brunei untuk bertemu dengan Sultan. Pemimpin yang diundang dari rantau Belaga terdiri dari Baliang, saudara sulung Sagiang yang pada waktu itu adalah bangsawan pemerintah orang Punan Bah di Long Bah; Matu, ketua Sekapan; dan Tama Tipong Tuloi, ketua Kejaman. "Menurut Punan Bah, hasil perjalanan itu adalah untuk mendirikan pusat perdagangan kecil di Belaga, namun begitu telah merosot apabila pentadbiran Brooke mendirikan kubu pertamanya di sini pada tahun 1884" (Nicolaisen 1976: 85).

Cerita versi masyarakat Kejaman yang diberitahu kepada Allen Maxwell (1999) bahawa Tama Tipong Tuloi membuat perjalanan seorang diri ke Brunei, bertemu dengan Nakuda Raman yang membawanya untuk bertemu dengan Sultan. Daripada perjalanan ini, Maxwell (1999: 153) menulis bahawa:

Tama Tipong telah mengembara ke Brunei dengan mengambil laluan darat lama di Lembah Balui, yang dibahagikan kepada Lembah Tubau dan mendayung ke Brunei dari sana, Tama Tipong memujuk Nakoda Raman untuk menemani beliau ketika beliau kembali ke Balui. Sultan Brunei, dilaporkan kagum dengan Tama Tipong Tuloi kerana dia telah mengambil laluan yang lebih sukar ke Brunei (tidak seperti Dian [B]ato’ yang telah mengambil laluan sungai ke pantai dan kemudian belayar ke Brunei). Sultan mengurniakan Tama Tipong dengan mahkota, bendera, gendang, dan penimbang yang sama seperti yang digunakan untuk menimbang sayuran. Sultan menjadikan Tama Tipong sebagai wakilnya di Belaga. Ini berlaku sebelum [Brooke] Low mendirikan kubu - kemudian dikenali sebagai Kubu Vyner.

Eksport Brunei sebahagian besarnya terdiri daripada hasil hutan. Metcalf (2010: 138177) menyenaraikan beberapa barang yang dibeli oleh pedagang-pedagang Melayu Brunei seperti kapur barus, damar, rotan, kayu gaharu, sarang burung, tanduk badak, dan batu-batu bezoar. Barang-barang ini perlu dikumpulkan oleh orang-orang pedalaman dari hutan dalam akan ditukarkan dengan barangan buatan Brunei, seperti kain, terutamanya kain songket yang terkenal dan bercorak, lampu tembaga minyak tanah, periuk tembaga, sireh pinang, meriam, dan peluru meriam. Tama Tipong berperanan sebagai wakil Sultan di hulu Rejang adalah untuk menggalakkan penyertaan masyarakat tempatan dalam perdagangan, dan yang paling penting dalam pengumpulan hasil hutan.

\footnotetext{
${ }^{10}$ Nicolaisen (1976: 85) mengatakan bahawa Tigeang adalah bapa saudara kepada Sagiang tetapi salasilah yang beliau paparkan di dalam artikel yang sama menunjukkan bahawa mereka merupakan saudara kandung dan merupakan anak lelaki kepada Salui dan isterinya Usun Dian.
} 


\section{Kubu Vyner dan pusat perdagangan}

Apabila Hugh Brooke Low menjadi Residen Bahagian Ke-3 yang berpangkalan di Sibu, beliau memutuskan untuk melawat Belaga "bagi mendapatkan maklumat mengenai bilangan dan lokasi penduduk setempat dan memulakan integrasi mereka ke dalam kerajaan Rajah Charles Brooke" (Maxwell 1987: 17). Matlamat khusus beliau adalah untuk menjelaskan dan membiasakan rakyat dengan cara kerja kerajaan Brooke, termasuk sistem cukai pintu. Beliau meninggalkan Sibu untuk Belaga pada 11 Mac 1882 dan berada di Kapit dalam perjalanan pulang ke Sibu, 25 April 1882 (Low 1882a, 1882b, 1882c, 1882d 1882e). Beliau mengkaji geografi hulu Rejang dan orang-orang yang menetap di sana selama 46 hari. Perlu diingat bahawa, sebelum ini, Residen yang berpusat di Mukah serta Residen di Bintulu menjaga pentadbiran di Belaga.

Dari pengalaman selama 46 hari beliau bergerak di sekitar hulu Rejang dan mengadakan perbincangan dengan setiap kumpulan di kampung mereka, beliau telah mengembangkan pengetahuan asas yang baik mengenai rangkaian sungai-sungai utama, geografi kawasan dan pelbagai kumpulan etnik yang hidup di sana. Berbekalkan pengetahuan ini, beliau membuat keputusan untuk membina sebuah kubu di pertemuan Belaga dan Balui sebagai pusat pentadbiran setempat untuk menjaga keamanan dan ketenteraman di kawasan itu, dan membuka jalan bagi penubuhan pusat perdagangan.

Dalam perjalanannya yang kedua, beliau meninggalkan Sibu pada 3 November 1883 dan berada di Kapit dalam perjalanan pulang ke Sibu pada 28 Februari 1884. Beliau berada di tempat tersebut selama hampir tiga bulan. Dalam perjalanan tersebut, beliau mengumpulkan 715 orang Iban dari pelbagai daerah Kanowit, Julau, dan Kapit, 19 orang dari Kanowit, 2 orang dari Tanjong, 24 orang dari Maloh, 25 orang dari Baketan, 12 orang dari Sihan, 18 orang dari Sibu Melanau, 29 orang dari Siduan Melanau, dan 35 orang Melayu untuk mengikutinya ke Belaga untuk membina Kubu dengan masyarakat setempat di sana (Low 1884d: 51). Bahan binaan seperti tiang, papan, bumbung telah disediakan oleh penduduk tempatan, seperti suku kaum Kajang (Sekapan, Kejaman, Lahanan, Punan Bah), Kayan, dan Kenyah (Low 1884b: 3940). Tapak yang dipilih adalah di antara pertemuan Belaga dan Balui di mana pusat perdagangan kecil itu dibina oleh pedagang-pedagang Melayu Brunei atas cadangan Ketua Punan Bah Balieg, ketua Sekapan Matu dan Ketua Kejaman, Tama Tipong Tuloi.

Brooke Low dan pengikutnya tiba di Belaga dan Balui pada 25 November 1883, mula bekerja di tapak kubu hari berikutnya, 26 November, dan menyelesaikan kerja mereka pada 13 Januari 1884. Projek ini terdiri daripada kubu berukuran 48 x 30 kaki, berek berukuran 84 x 30 kaki, dua buah rumah luar, dan sebuah kedai berukuran 30 x 18 kaki. Kerja-kerja penambahbaikan perlu dilakukan di kubu. Brooke Low dan pegawai tempatan datang ke Belaga membawa bersama mereka tukang kayu Cina dengan nama Ah Chong untuk melakukan kerja penambahbaikan di kubu (Maxwell 1999: 158).

Semasa kubu sedang dibina, peniaga-peniaga Melayu Brunei dan pedagang-pedagang Cina baru-baru ini juga sibuk membina rumah-rumah yang akan mereka gunakan untuk menjalankan perdagangan mereka. ${ }^{11}$ Peniaga-peniaga Melayu Brunei tidak syak lagi merupakan pedagang Burong Pingai yang sama diceritakan oleh de Crespigny dan Gueritz, sebagai pelopor Melayu Belaga. Catatan penting Brooke Low yang dimasukkan dalam buku hariannya pada 9 Januari 1884, adalah seperti berikut: "Janji Burong Pingai untuk tinggal di

\footnotetext{
${ }^{11}$ Temubual bersama Kapitan Teo Hee Tong di kedainya di Belaga, 24 Mei 2017
} 
rumah saya sementara mereka membina rumah mereka sendiri di belakang rumah saya. Rumah mereka berukuran 30 x 30 kaki" (Low 1884d: 52).

Semasa hujung tahun 1884, Brooke Low telah mengadakan perjumpaan di kubu yang telah dibinanya bersama 37 orang ketua dari pelbagai kawasan di Belaga, 24 daripada mereka adalah dari Balui, 10 Usun Apau dan enam orang mendiami kawasan berdekatan dengan kubu berkenaan (Anon. 1884: 94-95). Tujuan perjumpaan berkenaan adalah untuk menerangkan maksud cukai pintu dan untuk mengingatkan para ketua berkenaan untuk memberitahu serta memastikan setiap penduduk membayar cukai. Perkara yang paling penting dalam perjumpaan berkenaan bagi Residen tersebut adalah untuk mendengar pendapat setiap ketua termasuklah beberapa orang Iban dari hilir Rejang.

Pendapat yang sama yang diluahkan oleh setiap ketua adalah keinginan untuk kedamaian dan ketenteraman serta berikrar untuk taat setia kepada Rajah Sarawak. Tama Saghieng iaitu ketua Sebop dipandang tinggi oleh Residen kerana memberi kenyataan mengenai pusat perdagangan yang baru ditubuhkan di kawasan yang sama dengan kubu tersebut (Anon 1884: 94).

Seorang lelaki berusia yang bertubuh tinggi, mempunyai niat yang murni telah menyampaikan ucapan yang hebat. Dia hadir untuk kedamaian, peluang perdagangan serta bersetuju untuk patuh kepada pemimpin. Dia telah memberitahu orang Kenyah bahawa jika mereka tinggal berdekatan dengan Bazar mereka akan menjadi lebih kaya manakala jika mereka tinggal jauh daripada Bazar mereka akan menjadi lebih miskin. Dia telah mengangkat cawan buluh dan berkata "ini adalah cawan yang kamu gunakan untuk minum," selepas itu, dia mengangkat cawan porselin dan berkata "ini adalah cawan yang akan kamu gunakan untuk minum di masa hadapan jika kamu inginkan.” Kamu sendiri yang memutuskan. Yang mana yang kamu pilih, kamu orang Lepu Agas dan Badang, kami orang Lepu Anan, Sabop dan Blabit memilih pinggan mangkuk dibandingkan dengan buluh dan kain berbanding kulit kayu.

Sesudah kesemua ketua telah menyampaikan ucapan mereka, Residen berkenaan menyimpulkan bahawa "beliau berasa berpuas hati dengan apa yang telah diperdengarkan. Beliau tidak memerlukan sebarang ikrar. Beliau memilih untuk mempercayai kewibawaan mereka” (Anon. 1884: 95).

Pada tahun 1887 terdapat keraguan atas cadangan untuk mendirikan pusat kerajaan di tempat pertemuan Belaga dan Balui. H. F. Deshon, Residen Batang Lupar dan Saribas pada masa berkenaan telah diberitahu untuk menjalankan lawatan ke Belaga dan melakukan pentaksiran (Deshon 1887: 123-124). Semasa kedatangan beliau di Belaga, Native Officer ${ }^{12}$ dari Belaga iaitu Awang Sutuh, anak kepada seorang pedagang Melayu-Brunei, memberitahu Residen Deshon bahawa penduduk tempatan amat menghargai peranan pusat kerajaan dalam mengekalkan keamanan dan ketenteraman serta semakin ramai orang datang untuk berdagang daripada kawasan berdekatan termasuklah dari jauh. Dia juga telah memaklumkan kepada Residen berkenaan mengenai kuantiti barangan yang dibawa ke pusat perdagangan di Belaga serta pedagang yang kebanyakannya orang Melayu-Brunei, berasa gembira dengan adanya perlindungan dari kubu.

Setelah pulang dari Belaga, Residen Deshon telah menyatakan perasaan para pedagang yang terdiri daripada orang Melayu-Brunei dalam laporannya kepada Rajah yang telah

\footnotetext{
${ }^{12}$ Sebenarnya Awang Sutu[h] memegang jawatan sebagai Upriver Agent bukan Native Officer. Upriver Agent merupakan jawatan pangkat
} rendah yang lebih rendah dari Native Ofiicer atau Sarawak Administrative Officer 
diterbitkan dalam Sarawak Gazette pada 1 July, 1887, pp. 123-124. Kandungan laporan berkenaan adalah seperti berikut:

Atas pengumuman saya bahawa penubuhan Kerajaan akan ditarik balik, pedagangpedagang utama [Melayu Brunei dan Cina] dari tempat itu sekali gus menyuarakan kekesalan mereka. Mereka memberitahu bahawa mereka baru sedar akan kebaikan pusat kerajaan ditubuhkan di Belaga. Walaupun mereka telah lama melakukan perdagangan yang menguntungkan dengan orang Kayan dengan berjalan dari satu tempat ke tempat yang lain, mereka tidak pernah melihat aktiviti perdagangan yang amat rancak seperti yang berlaku sekarang. Mereka mengakui bahawa perkara ini berlaku disebabkan keadaan yang aman dan tenteram semenjak tertubuhnya pusat Belaga. Mereka menambah lagi, dengan memberitahu jika pusat kerajaan akan menarik balik perlindungan mereka, para pedagang masih lagi memilih untuk tinggal di Belaga.

Deshon juga telah berbincang dengan ketua-ketua utama di Belaga dan telah menyuarakan pendapat mereka dalam laporan yang sama seperti berikut:

Ketua-ketua orang Kayan, Matu, Tuloi, Mereng, Paren (a[ke’] Dian), Unsa serta yang lain yang telah menghadiri perjumpaan di Kubu telah menyatakan kekesalan mereka setelah mendengar berita bahawa pusat kerajaan akan ditarik balik. Mereka memberitahu bahawa perbalahan yang lama akan terjadi, pergaduhan akan berlaku dan perdagangan akan merosot. Saya berasa senang hati apabila mendengar luahan mereka kerana hal ini menunjukkan bahawa mereka amat menghargai ketenteraman di antara mereka dan berjanji untuk melaporkan perkara yang sama kepada Tuanku.

Dalam laporan beliau kepada H.H. Rajah, Residen Deshon mencadangkan bahawa pusat kerajaan di Belaga harus dikekalkan. Dia telah memberi lima sebab seperti berikut: 1) aktiviti perdagangan secara keseluruhannya akan terjejas; 2) pusat berkenaan telah dibangunkan untuk dua perkara: untuk mengekalkan keamanan dan ketenteraman serta untuk menggalakkan perdagangan berlaku dalam keadaan yang aman dan sejahtera; 3) penubuhan pusat perdagangan di Belaga tidak akan mengganggu jaringan perdagangan di Tubau dan Bintulu; 4) harapan perdagangan dengan Batang Kayan di Borneo Belanda tidak direalisasikan dan tidak mungkin akan berlaku jika pusat Belaga ditutup; dan 5) telah terdapat 11 buah kedai beroperasi di Belaga semasa lawatan Residen (Deshon 1887:123).

Di penghujung laporan, Residen berkenaan telah membuat kenyataam seperti berikut: "saya boleh katakan bahawa bangunan kerajaan termasuklah kubu, berek, rumah luar, taman serta ladang yang kesemuannya masih baru, akan membawa kerugian jika ditinggalkan begitu sahaja” (Deshon 1887 p. 133).

Rajah telah menerima cadangan Residen H. F. Deshon dan beliau memutuskan untuk mengekalkan kubu dan pusat kerajaan di Belaga. Keputusan berkenaan telah diterbitkan dalam Sarawak Gazette, 1 Ogos 1887 p. 133.

Dalam sekitar bulan Jun 1889, Residen Bamfylde telah mengembara ke Belaga dengan 100 orang pengikutnya. Air sungai pada masa tersebut adalah cetek serta jeram dapat dilalui dengan mudah dan mengikut Residen berkenaan, mereka mangambil masa sepanjang enam hari dari Kapit untuk sampai ke Belaga. Setelah sampai ke Belaga, beliau telah memberi kenyataan seperti berikut (Bamfylde 1889: 157-159):

Saya mendapati keadaan adalah bagus di Belaga; sejumlah pendapatan telah dibayar; akaun telah disimpan dengan tepat tetapi orang-orang yang bertugas di kubu telah menarik balik gaji mereka atas kegagalan korporal. 
Sebaik sahaja pembinaan kubu yang baru dijalankan, para pedagang berhasrat untuk menubuhkan sebuah bazar yang besar. Saya melihat tapak bazar dipenuhi dengan rotan serta pokok getah dan kapur barus dalam kuantiti yang banyak telah dikumpul; kayukayan untuk pembinaan kubu juga telah dipesan.

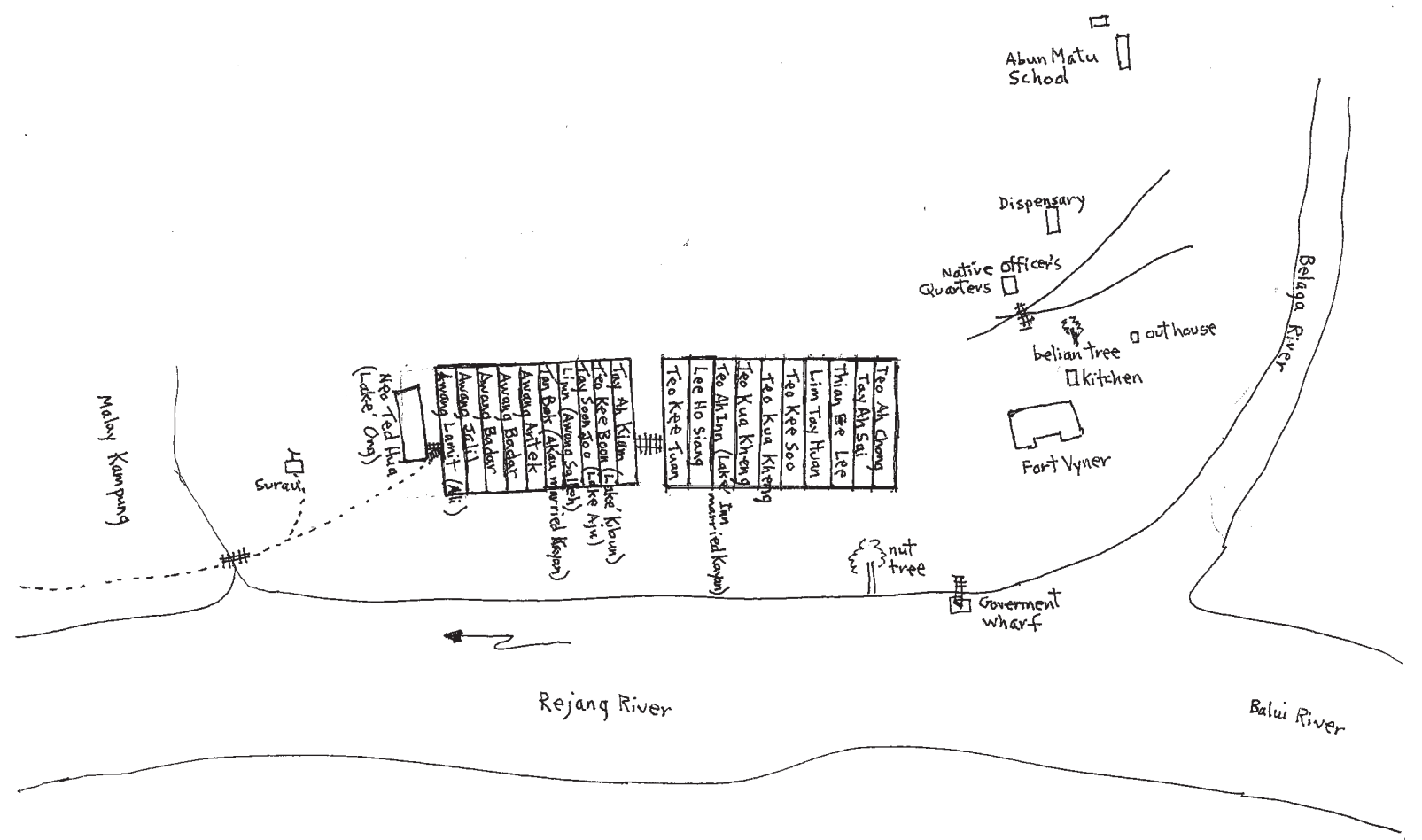

Rajah 1: Pasar Belaga pada awal 1950an (Langub 2016:139)

Residen telah melakukan perjumpaan dengan ketua-ketua seperti Matu, Tuloi dan lain-lain yang telah mengadu mengenai beberapa orang Kenyah yang telah berpindah sesuka hati tanpa menghiraukan arahan ketua untuk berpindah ke kawasan yang telah ditetapkan. Dalam Sarawak Gazette isu Februari 1893, Residen Bamfylde telah melawat Belaga. Dia berasa gembira melihat perkembangan yang telah berlaku semenjak lawatan beliau yang terdahulu. Dia menulis: Saya mendapati keadaan yang amat baik di Belaga. Pusat berkenaan membangun dengan pesat; terdapat 14 buah kedai di bazar dan 15 lagi akan dibina, 10 daripadanya dibina oleh orang Cina, lima orang Melayu; sebelum terbinanya kubu, hanya terdapat satu atau dua orang Cina sahaja di sini.

Lawatan rasmi Residen Julian Baring-Gould ke Belaga pada April 1901, 22 tahun selepas lawatan Residen Henry Deshon ke Belaga untuk menilai keperluan bagi mengekalkan kubu di sana adalah menarik kerana Residen berkenaan menegakkan keperluan untuk memiliki pusat perdagangan yang tetap serta kubu berkenaan adalah penting untuk mengekalkan undangundang dan ketenteraman (Baring-Gould 1909: 76-77). Mengimbas semula de Crespigny (1881b:7) pernah menyebut bahawa beliau berasa kagum terhadap kekayaan Belaga dari segi sumber hutan. Brooke Low juga sedar akan perkara ini setelah beberapa kali melawat Belaga dan perkara tersebut merupakan salah satu sebab beliau membina kubu di kawasan antara pertemuan Belaga dan Balui untuk memastikan aktiviti perdagangan yang adil. Selepas 28 tahun, pada tahun 1909, Julian Baring-Gould mengesahkan pemerhatian de Crespigny pada 1881 terhadap kekayaan sumber Belaga, oleh itu: 
Saya telah melawat orang Kenyah yang tinggal di kawasan sungai Belaga. Perjalanan itu adalah amat jauh dari pusat ke kampung yang pertama disebabkan jeram yang tidak dapat diredahi, kami terpaksa berpatah balik menggunakan laluan bukit. Dari hulu jeram ke Gunung Sepakau [Bukit Sepakau], kawasan berkenaan tidak mempunyai penduduk kerana suku kaum Kenyah telah hidup berselerak di bahagian hulu sungai. Hal ini amat mendukacitakan kerana bahagian negeri ini tidak didiami walaupun terdapat hutan yang kaya dengan pokok getah, kapur barus dan rotan yang dapat dibawa dengan mudah ke Bintulu melalui Sepakau.

Terdapat rotan dan juga hasil hutan yang lain dalam kuantiti yang besar di Bazar Belaga walaupun dengan keadaan pasar yang usang; satu kargo yang bernilai sebanyak $\$ 8,000$ telah dibawa menggunakan jalan air ke Kapit pada hujung bulan. ${ }^{13}$

Mengimbas semula kenyataan ketua-ketua utama Belaga iaitu Matu, Tuloi, Dian dan yang lain-lain yang diluahkan kepada Residen Deshon pada 1887 mengenai kepentingan untuk mengekalkan kubu untuk menjaga undang-undang dan ketenteraman di Belaga. Dalam laporan pada tahun 1909, Baring-Gould telah menyatakan kebimbangan beliau mengenai jumlah orang Iban yang mempunyai rekod jenayah, berkeliaran di Belaga:

Dua orang dayak [Iban] bernama Damu dan Jampi dijatuhkan hukuman penjara. Penjenayah pertama merupakan salah seorang daripada pengikut Baung yang telah menyertai serangan terhadap orang Badang dimana dia telah dikenakan saman namun gagal untuk membayar.

Penjenayah yang kedua pula telah dibuang daerah dari Belaga kira-kira dua tahun yang lepas dan dilarang untuk kembali namun telah mengingkari arahan berkenaan. Dia juga dikehendaki oleh mahkamah di Baram atas pertuduhan mengutip wang dengan menggunakan arahan palsu. ${ }^{14}$

Residen Deshon dapat melihat kebaikan untuk mengekalkan kubu yang menjamin undang-undang dan ketenteraman serta perdagangan yang adil. Perkara ini juga bermakna para pedagang Melayu dan Cina dijamin bahawa mereka akan mendapat kestabilan dan penempatan yang kekal di pusat perdagangan dibawah pengawasan pusat kerajaan.

\section{Perubahan ke arah cara masyarakat tempatan}

Perdagangan merupakan faktor utama yang membawa kepada kewujudan masyarakat Melayu di Belaga. Buktinya, aktiviti perdagangan di hulu Rejang didominasi oleh Melayu Brunei di bawah pengaruh Sultan Brunei. Masyarakat ini memainkan peranan yang penting dalam aktiviti perdagangan di lembangan Rejang walaupun setelah kawasan tersebut berada di bawah pengaruh kerajaan Brooke pada tahun 1861 yang dijaga oleh pegawai Brooke dari Mukah dan Bintulu (de Crespigny 1881a, 1881b; Gueritz 1881a, 1881b).

Pengaruh Sultan Brunei yang semakin berkurangan di kawasan lembangan Rejang selepas berlakunya pertukaran pengaruh pada 1861 dan pedagang Melayu sukar untuk mendapatkan barang dagangan dari Brunei. Bukan itu sahaja, kehadiran pedagang Cina yang mendapatkan barang dagangan dari Kapit atau Sibu memberi persaingan kepada pedagang Melayu. Selain itu, pedagang Cina mempunyai pelbagai aneka barang dagangan, seperti periuk belanga tahan karat, pinggan mangkuk, peralatan sudu dan garfu, besi (kebanyakannya digunakan untuk membuat parang), kain dan sebagainya. Para pedagang Melayu pula hanya berdagang barang-barang seperti periuk dan cerek tembaga, lampu tembaga minyak tanah,

\footnotetext{
${ }^{13}$ Julian Baring-Gould "Sibu," Sarawak Gazette, 1 April 1909 39(529), pp.76-77.

14 Julian Baring-Gould "Sibu," Sarawak Gazette, 1 April 1909 39(529), pp.76-77.
} 
kotak-kotak tembaga beraneka bentuk dan saiz, meriam tembaga, dan kain songket (kain tenunan daripada benang emas dan perak).

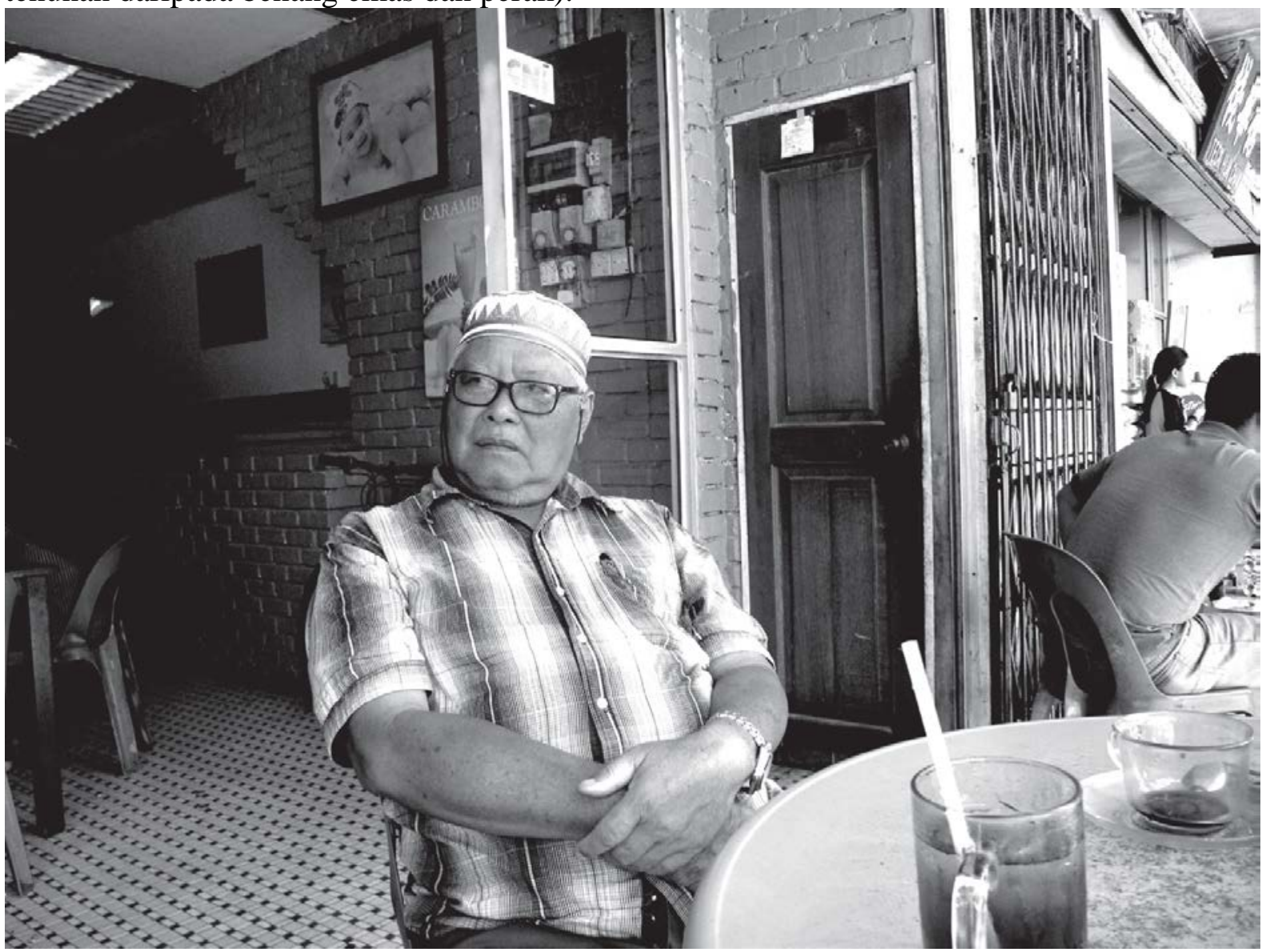

Gambar 5: Awang Radin, sila rujuk salasilah \#3 (Sumber gambar: J. Langub)

Sebelum penubuhan sebuah pusat pentadbiran di Sungai Belaga, terdapat dua orang pedagang Cina yang berdagang di Belaga. Perintis pertama Cina di Belaga, iaitu Neo Teoh Hua, mendakwa bahawa ayahnya pernah datang ke Belaga pada tahun 1880, yang pada ketika itu, pusat Belaga masih belum diwujudkan (Yao 1987: 19; Chew 1990: 88-89). Yao (1987) berpendapat bahawa penubuhan pusat kerajaan di antara Belaga dan Balui membawa kepada kekurangan pedagang Melayu dan peningkatan pedagang Cina. Pedagang Melayu mempunyai hubungan perdagangan yang kuat dengan Brunei, namun setelah lembangan Rejang jatuh ke tangan Rajah Brooke, hubungan tersebut semakin terjejas. Pedagang Cina di Belaga dan Balui mempunyai hubungan perdagangan yang baik dengan pedagang Cina yang berada di Rejang, di Kapit dan Sibu. Sukar bagi pedagang Melayu untuk memasuki jaringan perdagangan Cina di Kapit dan Sibu, dan bilangan pedagang Melayu di dua pusat perdagangan itu tidak ramai. ${ }^{15}$ Pada awal tahun 1950, terdapat 21 unit rumah kedai, 16 daripadanya dimiliki pedagang Cina dan lima lagi oleh pedagang Melayu. ${ }^{16}$

\section{Kehidupan Kampung}

Selama bertahun-tahun, pedagang Melayu mula membina tempat tinggal persendirian berasingan dari rumah kedai mereka, di hilir sungai, menjadi asas kepada Kampung Melayu pada hari ini. Surau juga telah dibina di antara kampung dan bazaar.

\footnotetext{
${ }^{15}$ Temubual bersama Awang Radin bin Awang Rajol di Bazar Belaga 24 Mei, 2017.

${ }^{16}$ Temubual bersama Kapitan Teo Hee Tong dan Awang Radin bin Awang Rajol 24 Mei, 2017. Empat orang Melayu yang memiliki rumah kedai tersebut adalah Awang Antek, Awang Badar(dua buah), Awang Jalil dan Awang Lamit.
} 


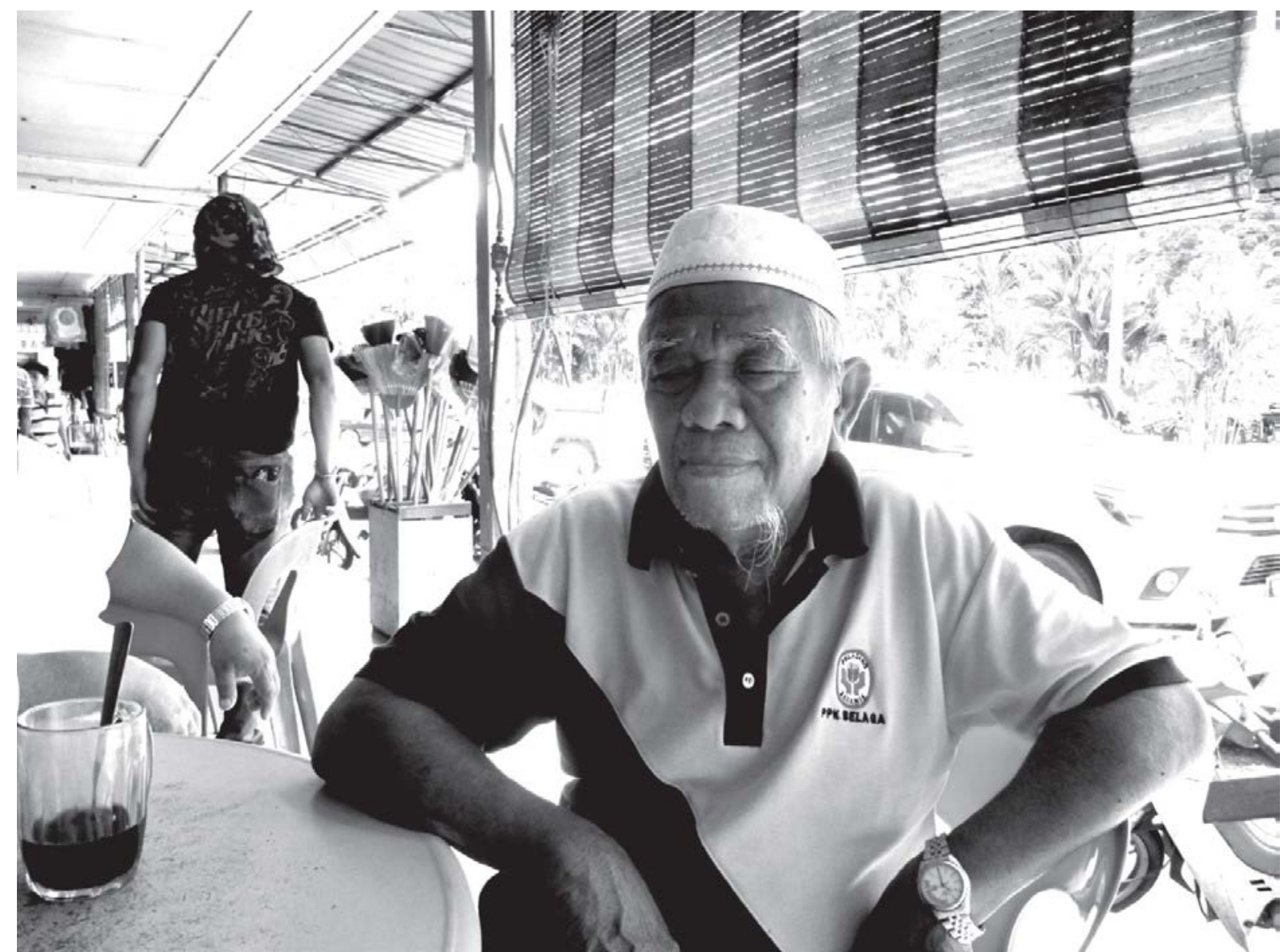

Gambar 6:Abang Suhai, Bilal Masjid Kampung Melayu Belaga, sila rujuk salasilah \#2. (Sumber gambar: J. Langub)

Surau tersebut yang kemudiannya menjadi sebuah masjid apabila Belaga menjadi sebuah daerah yang sah pada tahun 1973 dan dijadikan tempat bagi Muslim berkumpul dan beribadat. Kini, bilal ${ }^{17}$ bertanggungjawab menjalankan aktiviti keagamaan dalam komuniti, memanggil mereka untuk solat dan mengetuai mereka untuk beribadat. Sehingga sekarang, masih belum ada imam ${ }^{18}$ dalam komuniti tersebut dan kadang-kadang, imam daripada komuniti muslim Kenyah Badeng dari Long Busang di hulu Balui datang menziarahi masjid di Kampung Melayu Belaga, mengetuai solat dan menyampaikan khutbah.

Jawatankuasa Pengurusan dan Pentadbiran Masjid bertanggungjawab dalam menjaga dan memelihara masjid, cara-cara agama (untuk kanak-kanak dan dewasa), kesejahteraan sosial dalam komuniti dari segi perkahwinan dan penceraian, orang miskin, sakit (melawat mereka yang sakit di hospital atau di rumah mereka), bencana alam, kematian dan pengebumian, dan penyalahgunaan dadah. Jawatankuasa tersebut kini diketuai oleh penghulu komuniti, Penghulu Awang Robert bin Awang Osman, dengan ahli jawatankuasa yang termasuk bilal dan orang tua yang dihormati dalam komuniti.

Beberapa keluarga membeli tanah dari Sekapan dan memulakan penanaman beras bukit atau getah. Sehubungan dengan penanaman beras bukit, mereka menerima pakai adat tempatan iaitu kerjasama kumpulan dikenali sebagai paladau (Kayan) atau senguyun (Kenyah). Kumpulan ini ditubuhkan oleh petani-petani yang semuanya bertani di satu ladang selama satu hari. Mereka bertani secara bergilir-gilir di setiap ladang yang ada sehingga setiap ladang yang

\footnotetext{
${ }^{17}$ Bilal adalah muezzin atau orang yang melaungkan azan (seruan bagi memanggil Muslim untuk solat). Memandangkan tiada imam di belaga, bilal tersebut turut mengetuai mereka untuk beribadat.

${ }^{18}$ Imam merupakan orang yang bertanggungjawab untuk mengetuai orang Islam dalam mengerjakan ibadat dan imam merupakan orang yang terpilih dalam kalangan masyarakat kerana mempunyai pengetahuan mengenai al-Quran. Buat masa sekarang, komuniti Melayu di Belaga belum mempunyai imam. Imam dalam komuniti muslim Kenyah Badeng di Long Busang mendapat latihan formal mengenai alQuran di Institute Islam di Kuala Lumpur.
} 
ada telah diusahakan. Setiap ladang akan diusahakan dalam jangka masa yang sama yang telah ditetapkan oleh semua ahli dalam satu kitaran tempoh penanaman.

Mereka juga menerima pakai adat ngurang yang berkait dengan hari pertama penanaman. Pada waktu lewat tengahari sebelum hari penanaman, ahli keluarga datang untuk bermalam di pondok sementara yang telah dibina untuk aktiviti penanaman tersebut yang terletak di ladang salah seorang daripada ahli keluarga itu. Mereka akan memasak dan makan bersama-sama, bertukar-tukar cerita, bergosip atau pun berehat untuk beramah mesra antara satu sama lain. Lelaki dan wanita yang belum berkahwin turut berehat dan bergurau antara satu sama lain atau melibatkan diri dalam perbincangan kecil.

Keesokan harinya, lelaki-lelaki akan membuat lubang pada tanah yang sudah dibakar dengan kayu tugal, wanita-wanita menyusuli dari belakang meletakkan benih padi ke dalam lubang yang telah dibuat. Kerja selesai selepas makan tengahari. Wanita-wanita muda tiba-tiba menghilangkan diri dan menyorok di semak-semak sepanjang jalan ke kampung. Apabila pekerja berjalan pulang, wanita-wanita ini muncul keluar dari tempat persembunyian dengan tangan mereka yang penuh dengan jelaga hitam daripada sisa pokok terbakar di ladang ${ }^{19}$ dan mencomotkan muka-muka lelaki, terutamanya yang belum berkahwin. Dibalas pula oleh lelakilelaki dengan menarik tangan wanita-wanita ini ke muka mereka sendiri, mencomotkan muka mereka. Kekecohan tarik-menarik walaupun dengan kegembiraan dan hiburan berlaku selama beberapa minit, semuanya berasa seronok. Mereka berpuas hati dengan muka yang hitam, lalu pulang ke kampung dengan hati yang gembira.

\section{Kepimpinan Melayu}

Sewaktu saya bekerja di Pejabat Daerah Kecil Belaga pada tahun 1971, tiada senarai catatan pewarisan ketua kampung di Belaga. Maxwell (1999: 247-248) menyediakan dua senarai pewarisan dan mengaku bahawa pemberi maklumat tidak pasti kesahihan turutan kronologi tersebut. Saya menemu bual tiga pemberi maklumat ${ }^{20}$ dan diberi turutan kronologi untuk pewarisan tua kampung seperti berikut: Awang Taha kepada Awang Matnor, kepada Awang Salleh bin Awang Tabib, kepada Awang Salleh bin Awang Sulaiman, kepada Abdul Hamid bin Che Shoh, kepada Awang Osman bin Awang Draman, kepada Awang Aris bin Awang Jalil, kepada Awang Japar bin Awang Ahkbar, tua kampung sekarang. Ketiga-tiga pemberi maklumat dengan yakin menyatakan urutan kronologi yang mereka berikan ini betul. Jelas ternyata disini, kepimpinan ini nampaknya datang dari keluarga yang berketurunan daripada awang-awang Brunei. Hal ini berkemungkinan dari kelebihan mereka dari segi jumlah.

Sebuah kampung Melayu baru, Kampung Hijrah, Belaga ditubuhkan pada tahun 2014, dan tua kampungnya yang pertama ialah Abang Bujang bin Abang Suhaili. Beliau dilantik sebagai tua kampung pada bulan Januari 2016. Seperti dinyatakan sebelum ini, Kampung Hijrah ditubuhkan di kawasan yang baru bertentangan Sekolah Menengah Belaga kerana kekurangan tanah di kawasan asal, iaitu terletaknya Kampung Melayu, Belaga kini. 27 isi rumah yang berpindah ke Kampung Hijrah terdiri daripada mereka yang berketurunan dari Melayu Brunei, abang-abang Sadong dan keluarga Kedayan.

Sepanjang empat tahun bermastautin di Belaga, Abdul Hamid bin Che Shoh adalah tua kampung. Awang Osman bin Awang Draman pada masa itu pemandu kerajaan yang sudah bersara di Pejabat Mukim Belaga; kekosongan jawatan pemandu diambil alih oleh Awang Aris

\footnotetext{
${ }^{19}$ Komuniti Orang Ulu menggunakan jelaga hitam yang didapati dari

${ }^{20}$ Temubual bersama Awang Robert bin Awang Osman, 16 Januari 2017, Abang Suhai bin Abang Hashim dan Awang Radin bin Awang Rajol, 24 Mei 2017.
} 
bin Awang Jalil, beliau kemudian pada beberapa tahun selepas itu, bersara dan menjadi tua kampung setelah kematian Awang Osman bin Awang Draman sebagai tua kampung selepas kematian Abdul Hamid bin Shoh, abang tirinya. Selepas kematian Awang Aris bin Awang Jalil, Awang Japar bin Awang Ahkbar dilantik sebagai ketua kampung pada 1 Mac 2014. Hari ini, dua ketua kampung komuniti Melayu di Belaga ialah Awang Japar bin Awang Ahkbar dan Abang Bujang bin Abang Suhaili, kedua-dua merupakan pesara kerajaan. Pelantikan Abdul Hamid bin Shoh sebagai tua kampung menandakan titik permulaan kepimpinan Melayu kepada individu bukan pedagang. Ia juga mengisyaratkan penurunan Melayu Belaga sebagai komuniti perdagangan.

\section{Awang Sutuh bin Awang Taha, seorang Upriver Agent}

Awang Sutuh bin Awang Taha berkemungkinan Melayu yang terpenting pada awal zaman perkampungan Melayu di Belaga. Gueriz (1887: 123) menyebut namanya sebagai “Abang Sutu”; pemberi maklumat ${ }^{21}$ menjamin bahawa "Abang Sutu” yang disebut dalam laporan Gueritz dan Deshon itu adalah orang yang sama sebagai Awang Sutuh. Beliau dilantik sebagai Upriver Agent (U.R.A) untuk Belaga dan tandatangannya terdapat di pelbagai muka surat di dalam Buku Informasi Belaga (Belaga Information Book n.d.).

Deshon (1887: 123) menyebut Awang Sutuh sebagai N.O (Native Officer) apabila beliau sampai di Belaga untuk menentukan sama ada untuk menutup atau membiarkan pusat kerajaan di pertemuan antara sungai Belaga dan Balui. Pedagang utama dan ketua utama menyatakan kehendak mereka supaya pusat kerajaan tidak ditutup. ${ }^{22}$ Walaubagaimanapun, pengaruh Awang Sutuh membuat Deshon mengesyorkan kepada Rajah supaya pusat tersebut dikekalkan dan tidak diabaikan. Kini, pusat tersebut dijadikan sebagai sebuah bandar moden dan ibu pejabat bagi daerah Belaga.

Dalam Buku Informasi Belaga, Pegawai Daerah Kapit, John Fisher menggariskan beberapa tugas-tugas Upriver Agent di Belaga seperti terturut:

\#1 Dua kali setahun untuk melawat semua rumah [penempatan rumah panjang] di daerah Belaga.

\#2 Dua kali setahun untuk melawat Punan di Long Kajang dan membuat pengaturan untuk "mesyuarat” mereka. Untuk mengawasi perdagangan Punan dan melihat hasilnya dilelong dan dijual dengan adil.

\#3 Untuk mengarahkan penolong pegawai perubatan ke tempat yang harus ditujui apabila dia melawat Belaga.

\#4 Untuk mengemukakan laporan sekali sebulan mengenai urusan Belaga kepada saya di Kapit.

\#5 Untuk melaporkan dengan segera sebarang kejadian yang serius kepada saya di Kapit.

\#6 Untuk berhati-hati menjaga semua wang kerajaan dan mengambil segala langkah berjaga-jaga yang diperlukan untuk memastikan keselamatan yang terbaik.

\#7 Untuk merekod semua wang yang dikutip untuk Kerajaan dalam buku tunai dan disertakan sekali dengan setiap contoh resit.

\#8 Untuk menulis rekod harian tentang apa-apa kepentingan di dalam buku harian.

\footnotetext{
${ }^{21}$ Temubual bersama Penghulu Awang Robert bin Awang Osman 16 Februari 2017, dan Abang Suhai bin Abang Hashim, Awang Radin bin Awang Rajol, Kapitan Teo Hee Tong dan Lato Juman, iaitu Maren Uma, Uma Balo Kesing, Long Amo, Belaga 24 Mei 2017.

22 Mengikut kisah yang diceritakan secara turun-temurun, Awang Sutuh merupakan individu yang menyakinkan Residen Deshon untuk tidak menutup pusat kerajaan (maklumat diambil dari temubual saya bersama Penghulu Awang Robert, 16 Januari 2017 dan Kapitan Tee Heo Tong, Maren Uma Lato Juman dan Awang Radin, 24 Mei 2017). Tiada yang dapat menyangkal pendapat pedagang utama dan ketua masyarakat di Belaga yang turut sama menemui Residen Deshon. Nampaknya, gabungan pendapat dari Awang Sutuh, pedagang utama dan ketua masyarakat telah menyakinkan Residen Deshon untuk membatalkan penutupan pusat di Belaga.
} 
\#9 Memberi peringatan kepada orang tempatan jika mempunyai kesempatan:

[a] Untuk memastikan rumah mereka bersih terutama bahagian bawah rumah.

[b] Mengenai perubahan kuasa dan kepentingan mengikuti adat tempatan berdasarkan kaum masing-masing.

[c] Mengenai kepentingan meningkatkan bekalan padi yang mencukupi untuk keperluan individu mereka dan jika mungkin terdapat lebihan yang boleh dijual.

[d] Jangan mensia-siakan masa yang ada, kerana hasil penanaman padi hari akan datang mungkin akan lebih baik lagi pada sebelumnya. Dalam 100 itu kebarangkaliannya adalah 99 tidak baik. Setiap individu harus memahami bahawa padi adalah sumber penting bagi kehidupan mereka.

[e] Jangan tukar 70 peratus daripada tanaman padi yang baik ke "Borak" [arak beras]. Ini kegilaan semata-mata. Apabila tidak ada "Borak", orang boleh minum air tetapi ketika tidak ada padi, orang tidak boleh makan lumpur sebagai pengganti kepada nasi.

[f] Jika ada yang demam, jangan sekali-kali mereka mandi. Ini juga merupakan suatu kesilapan dan merupakan penyebab kepada wabak kematian pada tahun 1937. Lazimnya, selesema dan demam pada badan akan membawa kepada Pleurisy dan radang paru-paru.

Dalam beberapa muka surat Buku Informasi Belaga, Awang Sutuh, seorang Upriver Agent, ini dengan tekun terlibat dalam peristiwa penting seperti pelangsaian hutang, penerbitan perjanjian perikatan, pembayaran denda dari pelbagai makhamah melibatkan tua kampung dan penghulu. Setiap laporan yang ditarikhkan, ditandatangani “Awang Sutuh” dengan gelaran pangkat N.O. (Native Officer) dan dikehendaki ditandatangani oleh beberapa saksi. Perkara ini adalah kerana penggunaan jawatan N.O. oleh Awang Sutuh yang hanya seorang pegawai rasmi berpangkat rendah Upriver Agent amat diragui. Berkemungkinan, beliau diarah untuk menggunakan gelaran N.O. kerana pangkat ini merupakan pangkat rasmi yang sesuai untuk beliau mendaftarkan perjanjian perikatan, keputusan mahkamah dan perkara-perkara rasmi yang lain. Lagipun, beliau sedang menjalankan tugasnya sebagai N.O. daerah. Walaubagaimanapun, pangkat sebenar Awang Sutuh adalah Upriver Agent (U.R.A). Beliau melakukan kerja Native Officer walaupun secara tidak rasmi mungkin disebabkan Belaga berada jauh di luar dan pentadbiran sukar untuk mencari N.O. yang sanggup berkhidmat di sana pada bila-bila masa. Kita tidak pasti bagaimana pendapat Awang Sutuh berkenaan hal ini. Golongan orang berumur di Belaga yang saya jumpa pada tahun 1970-an memberitahu saya, sejauh mana yang mereka ketahui Awang Sutuh ialah N.O. mereka dan kemungkinan Awang Sutuh sendiri puas hati digelar seperti itu.

Pejabat kerajaan, sebagai contoh Pejabat Daerah dan Pejabat Daerah Kecil, diwujudkan bagi memastikan amalan perdagangan yang adil dan untuk menyemak berat dan ukuran. Rekod yang ditulis oleh Awang Sutuh dalam Buku Informasi Belaga menunjukkan beliau bekerja keras memastikan perdagangan berlaku dengan adil. Daniel Chew memetik dua contoh daripada Marudi dan Debak di mana pegawai tempatan didapati memihak kepada pedagang tertentu daripada yang lain, dan dihukum kerana tindakan mereka. Kisah mengenai perhubungan Awang Sutuh dengan pedagang serta orang awam menunjukkan beliau tidak berat sebelah dalam berurusan. Dua orang tertua yang ditemubual, Teo Hee Tong dan Lato Juman ingat bahawa Awang Sutuh ialah seorang yang mudah didekati dan dihormati oleh komuniti di Belaga. Mereka juga beranggap beliau memegang jawatan sebagai Native Officer dan bukannya Upriver Agent. 


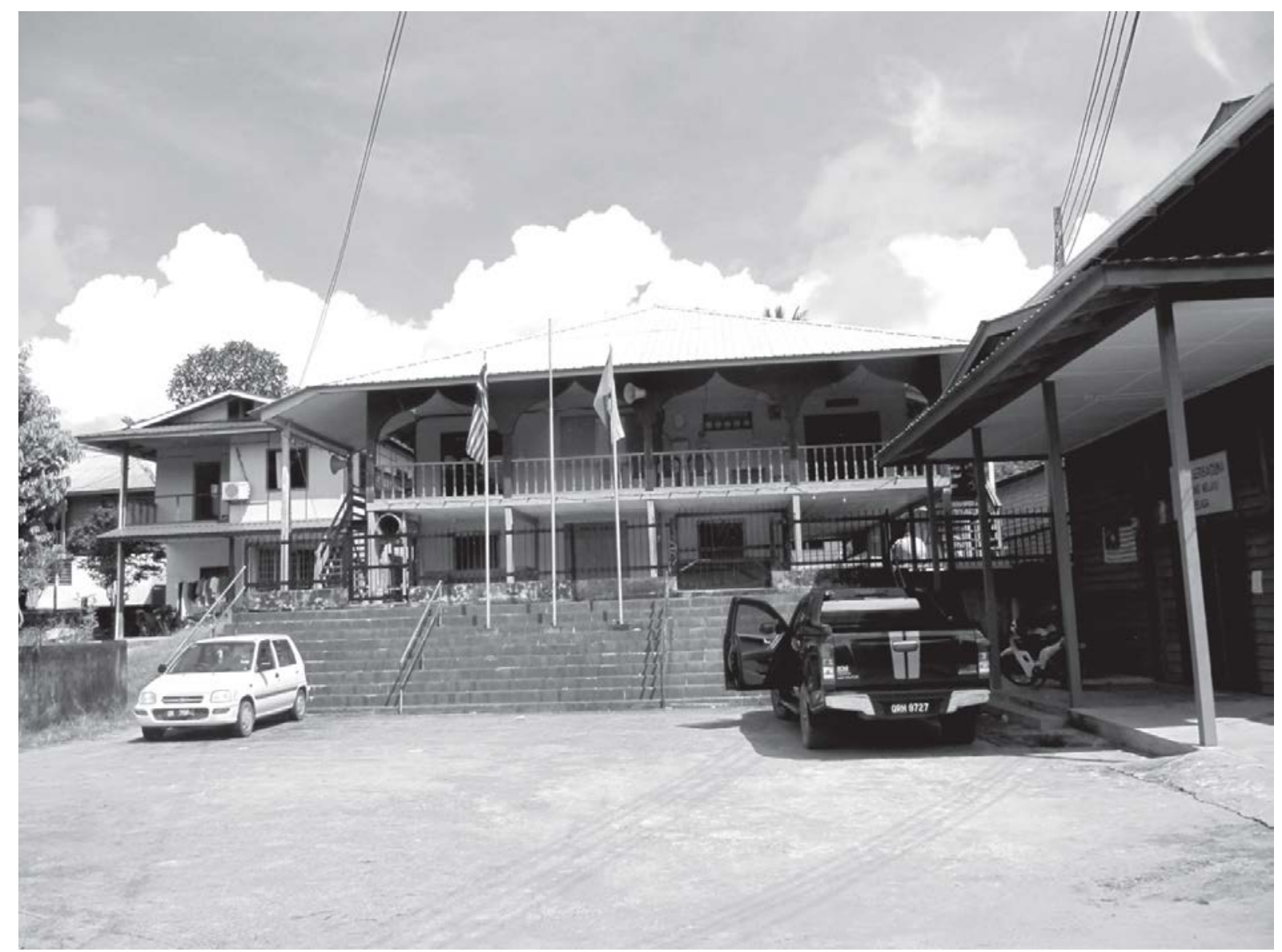

Gambar 7: Masjid Kampung Melayu Belaga dan Dewan Serbaguna disebelah kanan. (Sumber gambar: J. Langub)

Kapitan Teo Hee Tong dan Lato Juman berumur kira-kira 11 dan 13 tahun apabila kumpulan pertama tentera Jepun tiba di pekan Belaga ${ }^{23}$. Mereka mengingati keadaan di pekan ketika itu sangat senyap dan tiada aktiviti perniagaan berlaku. Ramai orang di sekeliling pekan, termasuk Melayu dan Cina yang tinggal di pondok ladang dan menanam tanaman makanan seperti beras, ubi, pokok buah dan sayur-sayuran. Upriver Agent, Awang Sutuh, jarang melawat Kubu Vyner, pejabat kerajaan, tetapi menggunakan hampir seluruh masanya untuk bercucuk tanam. Lato mengingat bahawa lima orang tentera Jepun tinggal di Kubu Vyner dan Awang Sutuh jarang-jarang melawat atau dipanggil ke situ.

Apabila tentera Australia datang, suasana di pekan menjadi lebih hidup dan beraktiviti. Ramai orang di rumah panjang di sekitar kawasan menolong tentera Australia dan mengangkut mereka melalui sungai, dengan mendayung perahu. Melayu dan Cina juga sukarela membantu.

Kapitan Teo dan Lato tidak pernah mengenang sebarang pergaduhan dalam atau di mana-mana kawasan pekan Belaga, walaupun mereka ingat mengenai perbalahan antara sukarelawan Iban dan tentera Jepun di Pasir Nai, di atas jeram Pelagus, Daerah Kapit.

Apabila perang berakhir, Awang Sutuh meneruskan jawatannya sebagai U.R.A. Seorang N.O. yang berpusat di Pejabat Daerah di Kubu Sylvia kadang-kadang datang ke Belaga untuk membantu Awang Sutuh menjalankan tugasnya. N.O. tersebut akan bermalam di Belaga dalam tempoh lebih kurang seminggu pada setiap lawatannya.

\footnotetext{
${ }^{23}$ Temubual bersama Kapitan Teo Hee Tong dan Lato Juman pada 24 Mei 2017
} 
Pada 11 September 1946, Awang Sutuh membuat catatan di muka surat 65 Buku Informasi Belaga mengenai pemindahan lot kedai No. 17 daripada Awang Badar kepada Awang Antek dengan jumlah \$1,125.00 (Straits Dollar). Ini merupakan catatan terakhir beliau dalam buku tersebut, dan catatan-catatan selepas itu ditandatangani oleh N.O. yang seterusnya.

\section{Hubungan sosial}

Hubungan antara orang Melayu dan orang asli Belaga adalah mesra, dengan saling menghormati. Walaupun mendapat sokongan daripada Sultan Brunei, kumpulan pertama pedagang-pedagang Melayu Brunei menjalankan perdagangan mereka "dari suku kaum ke suku kaum" dengan cara yang teratur apabila datang ke hulu Rejang (Nicolaisen 1983: 197). Mengimbas kembali kisah Punan Bah Sagiang yang menghabiskan sepuluh tahun di mahkamah Sultan Brunei, dan dihantar ke Tubau, adalah mungkin untuk memastikan berlakunya perdagangan yang adil dan keselamatan para pedagang terjamin. Sagiang juga mengatur beberapa lawatan ketua-ketua termasuk Baliang dari Punan Bah, Matu ketua kaum Sekapan, dan Tama Tipong Tuloi ketua Kejaman, untuk bertemu dengan Sultan. Pertemuan itu menghasilkan penubuhan pusat perdagangan sementara yang kecil di pertemuan antara Belaga dan Balui sebelum Hugh Brooke Low menubuhkan pusat kerajaan di sana pada tahun 1884 (Nicolaisen 1976: 85).

Mengimbas kembali cerita lisan Kejaman yang menunjukkan bahawa Tama Tipong Tuloi mengembara dengan kumpulannya sendiri ke Brunei; menjalin hubungan persahabatan Nakuda Raman bin Jawatan Gadong yang memperkenalkannya kepada Sultan. Berbangga dengan Tama Tipong, Sultan melantik Tama Tipong sebagai wakilnya (penyuroh) di kawasan hulu Rejang (Maxwell 1999: 153). Tama Tipong dibawakan dengan mahkota (makuta), bendera (bandira), gendang (gandang), dan penimbang (dacing) yang serupa dengan yang digunakan untuk menimbang sayur-sayuran (Maxwell 153: 153). Bagi membalas jasa atas persahabatan yang diberikan kepadanya, Tama Tipong mengundang Nakuda Raman ke Belaga untuk berdagang.

Pada mulanya, hubungan para pedagang dan penduduk tempatan menjadi lebih akrab adalah disebabkan perkahwinan. Perkahwinan pertama antara seorang pedagang Melayu dan seorang wanita tempatan adalah antara Tunku Ali, seorang pedagang Melayu Sumatera dan Hurieng, seorang wanita Kayan dari Batu Kalo (Rendah 1884c: 51-55). Malangnya Tunku Ali dibunuh, dan Hurieng yang memeluk agama Islam telah berkahwin lagi kepada Ampuan Drahman, penjaga Kubu Vyner. Informan tidak pasti sama ada Tunku Ali dan Hurieng mempunyai anak hasil daripada perkahwinan mereka.

Satu lagi perkahwinan antara peniaga Melayu Sumatera dan seorang wanita tempatan adalah antara Ibrahim Shah ${ }^{24}$ dan seorang wanita tua Punan Bah yang dikenali sebagai Aki Urum. Terdapat dua orang anak perempuan hasil dari perkahwinan mereka, iaitu Latipah dan Zainab, kedua-dua peniaga Melayu yang berkahwin, menghasilkan beberapa keturunan yang

\footnotetext{
${ }^{24}$ Maxwell (1999: 110) menyatakan bahawa di dalam salasilah, nama pedagang dari Sumatera yang yang mengahwini wanita Punan Bah tersebut adalah Inci Sam dan nama wanita tersebut tidak dinyatakan). Anak perempuan dari perkahwinan ini bernama Tipah yang mengahwini pedagang Melayu Brunei yang iaitu Awang Rahman dan mereka juga mempunyai dua lelaki iaitu Awang Abdul Hamid dan Awang Osman. Informan saya Awang Robert merupakan anak kepada Awang Osman mengatakan bahawa nama pedagang dari Sumatera itu ialah Ibrahim Shah dan isterinya yang berketurunan Punan Bah bernama Aki Urum. Ada dua orang anak perempuan dari perkahwinan tersebut yang diberi nama Latipah dan Zainab. Latipah pernah berkahwin sebanyak dua kali ; pertama dengan lelaki Melayu dari Terengganu yang bernama Che Soh. Mereka mempunyai seorang anak lelaki iaitu Abdul Hamid bin Che Soh. Abdul Hamid merupakan Tua Kampung di Belaga semasa saya menetap di sana pada tahun 1971-1974 dan Namanya tidak mempunyai awalan "Awang". Latipah kemudiannya mengahwini Awang Rahman dan mendapat seorang lagi anak lelaki yang bernama Awang Osman. Informan saya memberitahu bahawa Abdul Hamid dan Awang Osman merupakan adik-beradik tiri seibu. Abdul Hamid tidak berkahwin manakala Awang Osman mempunyai anak dan cucu yang ramai. Ibrahim Shah dan Aki Urum juga mempunyai pewaris yang ramai di Kampung Melayu Belaga melalui kedua anak perempuan mereka iaitu Latipah dan Zainab (rujuk salasilah).
} 
sebahagiannya berkahwin dengan wanita tempatan, akan dibincangkan secara terperinci kemudian.

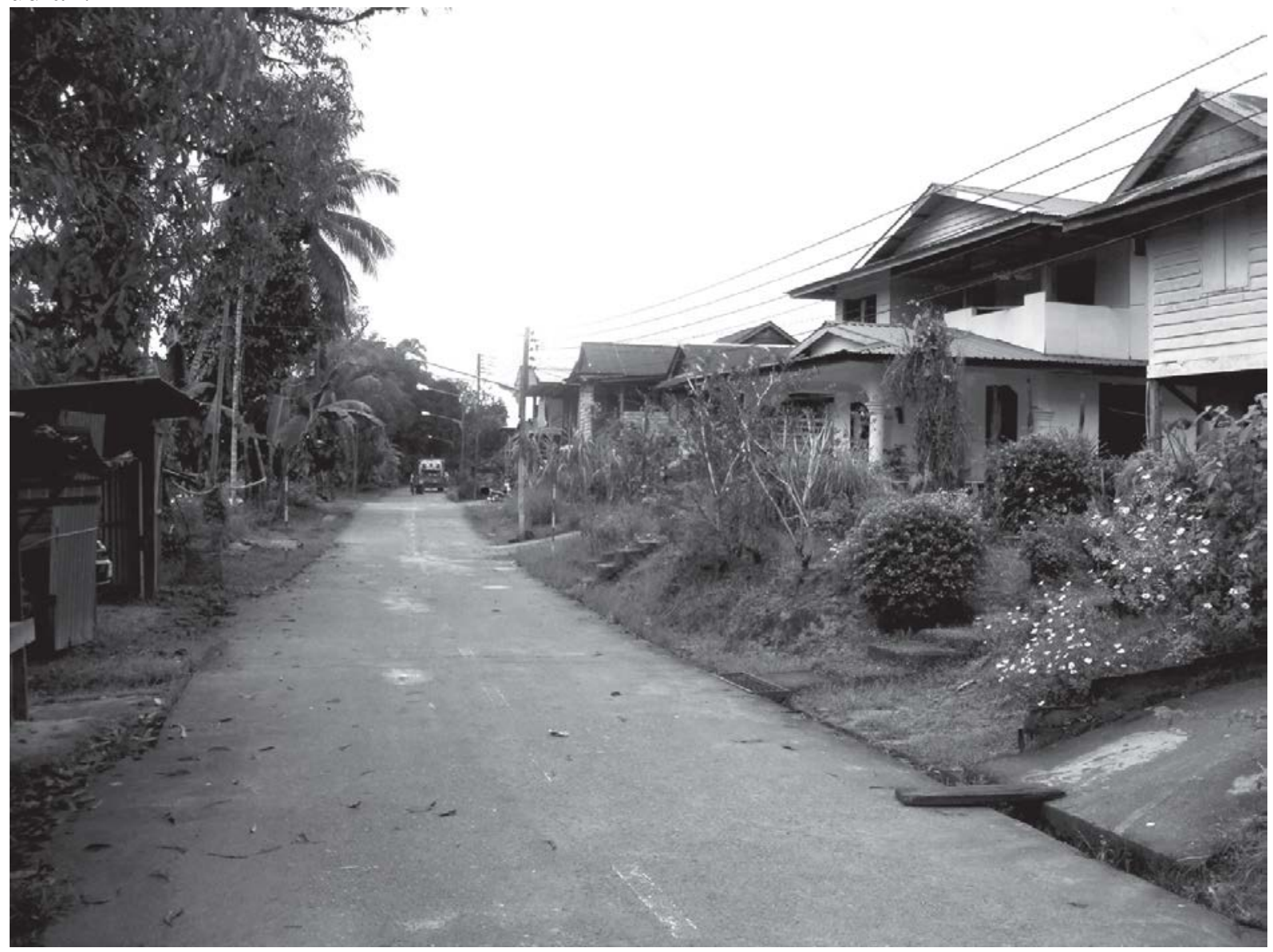

Gambar 8: Rumah di Kampung Melayu, Belaga (Sumber gambar: Kelvin Egay)

Pedagang Melayu awal mempelajari bahasa tempatan dengan orang yang mereka berniaga, terutamanya Kayan, yang kemudiannya menjadi lingua franca Daerah Belaga. Hari ini, hampir semua orang Melayu di Belaga bercakap bahasa Kayan dengan lancar. Sebilangan besar individu yang mempunyai ikatan darah dengan Sekapan, Punan Bah, Kejaman dan Lahanan, juga bercakap bahasa lain, di samping bahasa Kayan. Kemahiran dalam bahasa tempatan memudahkan perhubungan sosial antara masyarakat Melayu dan masyarakat tempatan.

Peniaga-peniaga Melayu Brunei telah berdagang dengan orang-orang di hulu Rejang lama sebelum lembah Rejang berada di bawah pemerintahan Brooke pada tahun 1861. Beberapa pedagang Melayu sudah fasih dalam bilangan bahasa tempatan, terutama Kayan, ketika orang Cina pertama tiba di Belaga pada tahun 1880 (Chew 1990: 88), menunjukkan bahawa mereka telah berdagang di sini selama bertahun-tahun dan sudah biasa dengan kawasan tempatan dan rakyatnya. Hubungan antara pedagang-pedagang Melayu dan Cina adalah mesra dan saling menghormati. Ini tidak seperti hubungan antara peniaga Melayu dan Cina di beberapa bahagian lain di Sarawak. Daniel Chew (1990: 133-134) memberi contoh daripada Sarawak Gazette persaingan dan konfrontasi antara pedagang Melayu dan Cina di Marudi dan Debak.

Pada tahun 1885, satu pergaduhan berlaku antara pedagang-pedagang Melayu dan pedagang Cina di Marudi atas sebab yang tidak diketahui. Hubungan antara kedua-dua komuniti itu begitu teruk sehingga pada tahun 1909 orang Cina memohon Residen untuk melucutkan jawatan Kebar sebagai seorang jurutulis laporan mahkamah Melayu atas dasar pilih 
kasih terhadap pedagang Melayu Brunei dan mengabaikan tugasnya. Residen memutuskan bahawa pedagang-pedagang Melayu Brunei telah bersikap bongkak dan diberi amaran untuk tidak mengganggu perdagangan orang Cina.

Pada tahun 1928 konfrontasi utama berlaku antara orang Melayu dan Cina di Debak yang melibatkan seluruh penduduk kedua-dua komuniti. Sebab utama ialah pedagang Melayu diberi kebenaran ke rumah panjang untuk membeli getah di situ manakala pedagang Cina tidak diberi kebenaran yang sama. Pada perbicaraan rasmi kes itu, N.O., Sidek dan Tua Kampung telah dilucutkan jawatan mereka oleh Residen setelah didapati bahawa mereka yang menyebabkan masalah itu.

Berbeza dengan keadaan di Belaga. Mengimbas kembali bahawa kedua-dua komuniti itu bekerjasama untuk menubuhkan sebuah pusat perdagangan kecil pada tahun 1884. Namun, pada tahun 1887, kerajaan bercadang untuk menutup pusat kerajaan di Belaga, kedua-dua komuniti ini bekerjasama untuk membuat rayuan kepada kerajaan untuk tidak menutup pusat kerajaan. H. F. Deshon, Residen Batang Lupar dan Saribas diminta mengunjungi Belaga untuk membuat penilaian mengenai permintaan tersebut. Ketika kembali ke Belaga, Resident Deshon (1887: 123-124) menyampaikan isi hati para pedagang utama (pedagang Melayu Brunei dan pedagang Cina) dalam laporan kepada Rajah yang diterbitkan dalam Sarawak Gazette seperti berikut:

Atas pengumuman saya bahawa penubuhan pusat kerajaan akan ditarik balik, pedagang-pedagang utama [Melayu Brunei dan Cina] dari tempat itu sekali gus menyuarakan kekesalan mereka. Mereka berkata bahawa mereka mula sedar akan kebaikan pusat Kerajaan yang ditubuhkan di Belaga. Walaupun, mereka telah lama melakukan perdagangan yang menguntungkan dengan orang Kayan dengan berjalan dari satu tempat ke tempat yang lain, mereka tidak pernah melihat aktiviti perdagangan yang amat rancak seperti yang berlaku sekarang. Mereka mengakui bahawa perkara ini berlaku atas keadaan yang aman dan tenteram semenjak tertubuhnya pusat Belaga. Mereka menambah lagi, dengan memberitahu jika pusat kerajaan akan menarik balik perlindungan mereka, para pedagang masih lagi memilih untuk tinggal di Belaga.

Dengan sokongan ketua-ketua utama di Belaga mereka berjaya meyakinkan pemerintah agar tidak menutup stesen itu. Keputusan itu diterbitkan di Sarawak Gazette (1 Ogos 1887, halaman 133) seperti berikut:

\section{REJANG}

H.H Rajah mendapati bahawa laporan Encik Deshon di negeri Pelaga [Belaga] Kubu memberi kesan kepada kedua-dua pedagang dan penduduk maka mereka berhasrat agar pusat kerajaan tersebut dikekalkan - kini telah memberi petunjuk bahawa kedudukan dan penubuhan Kerajaan di sana tidak boleh ditinggalkan.

Kedua-dua pedagang Melayu dan Cina meneruskan perdagangan mereka di bawah perlindungan kerajaan yang berpusat di kubu. Sejak bertahun-tahun, bilangan para pedagang Cina meningkat, sementara bilangan pedagang-pedagang Melayu semakin berkurangan. Orang Melayu perlahan-lahan mula menyesuaikan diri dengan kehidupan biasa kampung Melayu bersebelahan dengan pekan.

Pada Januari 2018, Institut Pengajian Borneo, Universiti Malaysia Sarawak telah menerbitkan laporan Komuniti Kampung Melayu Belaga, yang menerangkan mengenai salah satu daripada dua Kampung Melayu di Belaga, iaitu Kampung Melayu. Dalam sektor pekerjaan, laporan itu menunjukkan bahawa hanya 49\% penduduk yang tinggal di kampung mempunyai 
pekerjaan (Institut Pengajian Borneo 2018: 20). Pecahan pekerjaan menunjukkan bahawa 36 orang (18\%) bekerja dalam perkhidmatan awam, 21 orang (10\%) dalam sektor swasta, 17 orang (8\%) bekerja sendiri, 9 orang (4\%) bekerja sebagai petani, 8 orang $(4 \%)$ menceburi bidang perniagaan, 5 orang (3\%) bekerja sebagai nelayan dan 3 orang (2\%) melakukan aktiviti pemburuan.

Data pekerjaan menunjukkan bahawa kebanyakan penduduk bekerja dalam sektor kerajaan dan swasta, atau bekerja sendiri, termasuk perniagaan kecil-kecilan. Daripada pekerjaan ini, perkhidmatan kerajaan dan sektor swasta, memerlukan individu yang mempunyai tahap pendidikan formal yang tinggi. Laporan Komuniti Kampung Melayu Belaga melaporkan bahawa Kampung Melayu Belaga telah menghasilkan 7 orang yang berpendidikan tinggi, 24 orang berpendidikan Sijil Tinggi Pelajaran Malaysia (Tingkatan 6) dan 47 orang berpendidikan Sijil Pelajaran Malaysia (Tingkatan 5).

\section{Salasilah tujuh pasangan}

Sejumlah salasilah telah disediakan untuk saya semasa penyelidikan saya, tujuh daripadanya dibentangkan di bahagian ini. Dalam hampir semua salasilah ini keturunan mereka menghubungkan individu tertentu ke pelbagai nenek moyang dengan keturunan dari Sumatera, Brunei, Sadong, Sibuti, dan / atau rumah panjang di Belaga.

Dengan siapnya Jalan Belaga-Bakun pada tahun 2013, yang kini menghubungkan Belaga ke Miri dan Brunei; sekumpulan orang Melayu dari Belaga melakukan perjalanan ke Kampung Burong Pingai dan Kampung Tamoi di Brunei untuk memberitahu penduduk dari kampung ${ }^{25}$ ini bahawa nenek moyang mereka datang dari sana. Setelah itu, konvoi enam buah kenderaan pacuan empat roda bertolak melawat Kampung Melayu Belaga. Ketika menjelang akhir tahun 2017, satu perhimpunan besar "Pertemuan Sanak Saudara Burong Pingai" ${ }^{26}$ telah dianjurkan di Bintulu bagi keturunan dari Burung Pingai, yang kini tinggal di bahagianbahagian lain Sarawak dan Brunei ${ }^{27}$. Beberapa orang Melayu dari Belaga melakukan perjalanan ke Bintulu untuk menghadiri acara tersebut. Antara 27 dan 30 September 2018, sekumpulan Sanak Saudara Burong Pingai dari Brunei datang ke Belaga dalam enam buah kenderaan pacuan empat roda untuk menghadiri Belaga Regatta dan melawat saudara-mara. Pada perhimpunan tidak rasmi, ketua kumpulan Brunei memberitahu waris mereka di Belaga, dalam ucapan santai, bahawa jalan raya antara bandar Belaga dan Bakun perlu ditambahbaik dan dikekalkan jika mereka ingin saudara mereka dari Brunei datang berkunjung. ${ }^{28}$ Tidak pasti sama ada ucapan tersebut satu gurauan atau tidak, perlu diingatkan bahawa jalan tersebut sukar untuk dilalui.

Tidak ada lawatan antara orang Melayu Belaga dan saudara-saudara mereka dari keturunan abang-abang di Sadong. Begitu juga dengan Kedayan di Sibuti. Orang Melayu terus berhubung dengan saudara-saudara Orang Ulu mereka di Belaga secara tidak rasmi di bazar atau dengan melawat ke rumah panjang. Mereka juga melawat antara satu sama lain pada harihari perayaan seperti Hari Raya dan Pesta Menuai.

\footnotetext{
${ }^{25}$ Temubual bersama Penghulu Awang Robert, January 2017

${ }^{26}$ Temubual bersama Awang Japar, 31 Oktober 2018

${ }^{27}$ Temubual bersama Awang Japar, 31 Oktober 2018

${ }^{28}$ Jalan Belaga-Bakun merupakan projek yang dilaksanakan oleh jurutera Tentera Malaysia di bawah projek Jiwa Murni, strategi sama pernah digunakan oleh British dan Angkatan tentera dari negara-negara Komanwel semasa konfrontasi (dari tahun 1963-1966) untuk memenangi hati penduduk tempatan.
} 


\section{Pasangan \# 1: Awang Robert dan Dayang Uteh}

Awang Robert adalah seorang pemandu yang telah bersara dari Polis Diraja Malaysia yang berpangkalan di Belaga. Beliau merupakan penghulu terkini di komuniti Melayu di Belaga. Bapanya, Awang Osman merupakan anak kepada Awang Rahman, seorang pedagang Melayu dari Kampung Tamoi, Brunei. Nenek dari sebelah bapa beliau adalah Latipah, anak kepada seorang pedagang Melayu Sumatera, Ibrahim Shah dan seorang wanita Punan Bah yang bernama Aki Urum.

Ibu Awang Robert adalah Dayang Senol, anak kepada Awang Badar, seorang pedagang Melayu dari Kampung Burong Pingai dan Zainab, anak kepada Ibrahim Shah, adalah seorang pedagang Melayu Sumatera dan seorang wanita Punan Bah yang bernama Aki Urum.

Bapa dan ibu Awang Robert sebenarnya ialah sepupu kerana ibu kepada ibu bapa Robert merupakan adik-beradik. Awang Robert juga dapat menjejak keturunannya yang mempunyai kaitan dengan dua kampung di Brunei, iaitu Kampung Burong Pingai dan Kampung Tamoi, serta kampung yang tidak diketahui di Sumatera dan Kampung Punan Bah dari Long Bah di daerah Belaga.

Isteri Awang Robert adalah Dayang Uteh, anak perempuan Abang Hashim dan Dayang Halimah hasil perkahwinan silang. Abang Hashim dan Dayang Halimah ialah sepupu. Bapa Hashim yang bernama Abang Sumar bin Abang Sulaiman merupakan abang kepada ibu Dayang Halimah, Dayang Jelihah binti Abang Sulaiman. Abang Sumar telah berkahwin dengan seorang wanita Kayan yang bernama Livan, dan Dayang Jelihah telah berkahwin dengan seorang pedagang Melayu yang bernama Awang Serudin berasal dari Kampung Burong Pingai, Brunei.

Dayang Uteh dapat menjejak keturunannya daripada keluarga abang-abang dari Sadong di Barat Sarawak melalui bapanya (Abang Hashim) dan juga ke Kampung Burong Pingai melalui datuk (Awang Serudin) dari sebelah ibunya. Dia juga boleh menjejak keturunannya di Batu Kalo yang merupakan sebuah perkampungan Kayan melalui nenek (Livan) dari sebelah bapanya.

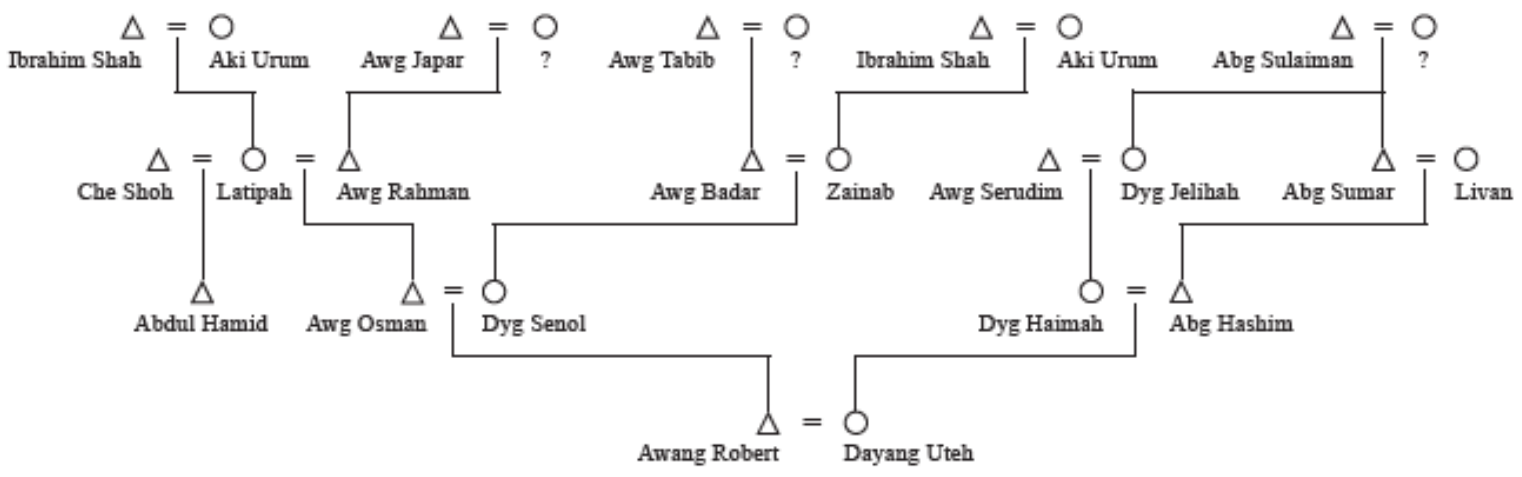

Salasilah 1: Awang Robert dan Dayang Uteh

\section{Pasangan \#2: Abang Suhai dan Dayang Sa'erah}

Abang Suhai merupakan penjawat awam yang telah bersara. Beliau telah ditugaskan dalam projek pembasmian malaria di Jabatan Perubatan dan Kesihatan, Belaga. Kini beliau merupakan bilal ${ }^{29}$ di surau ${ }^{30}$ tempatan.

\footnotetext{
${ }^{29}$ Di Malaysia, bilal merupakan muazzin

${ }^{30}$ Di Malaysia, surau merupakan tempat ibadat
} 
Bapa Abang Suhai yang bernama Abang Hashim, merupakan anak kepada Abang Sumar bin Abang Sulaiman yang berasal dari Sadong, dan Livan, wanita Kayan yang berasal dari Batu Kalo, Belaga. Ibu Abang Suhai, Dayang Halimah merupakan anak kepada Awang Serudin, seorang pedagang Melayu dari Kampung Burong Pingai, Brunei, dan bapa Dayang Jalihah dari Sadong di Barat Sarawak. Dalam erti kata lain, keturunan Abang Suhai mempunyai kaitan dengan abang-abang atau perabangan di Sadong dari Barat Sarawak, Kampung Burong Pingai di Brunei, dan Batu Kalo di Belaga.

Isteri Abang Suhai adalah Dayang Sa'erah, anak kepada Awang Ahmad yang merupakan anak kepada Awang Sutuh yang telah dinyatakan sebelum ini, memainkan peranan penting dalam pentadbiran daerah Belaga pada awal pembentukannya. Bapa Awang Sutuh bernama Awang Taha, seorang Melayu Brunei dari Kampung Burong Pingai di Brunei, dan juga merupakan salah satu pemimpin Melayu terawal, dikenali sebagai tua kampung pada masa kini di Kampung Melayu yang baru ditubuhkan di Belaga.

Ibu Dayang Sa’erah bernama Dayang Keci merupakan anak kepada Awang Matnor dari Kampung Burong Pingai dan Dayang Kuyah, seorang wanita Melayu dari Kuching. Selain daripada neneknya yang berasal dari Kuching di Barat Sarawak, keturunan Dayang Sa'erah mempunyai kaitan dengan keturunan di Kampung Burong Pingai di Brunei.

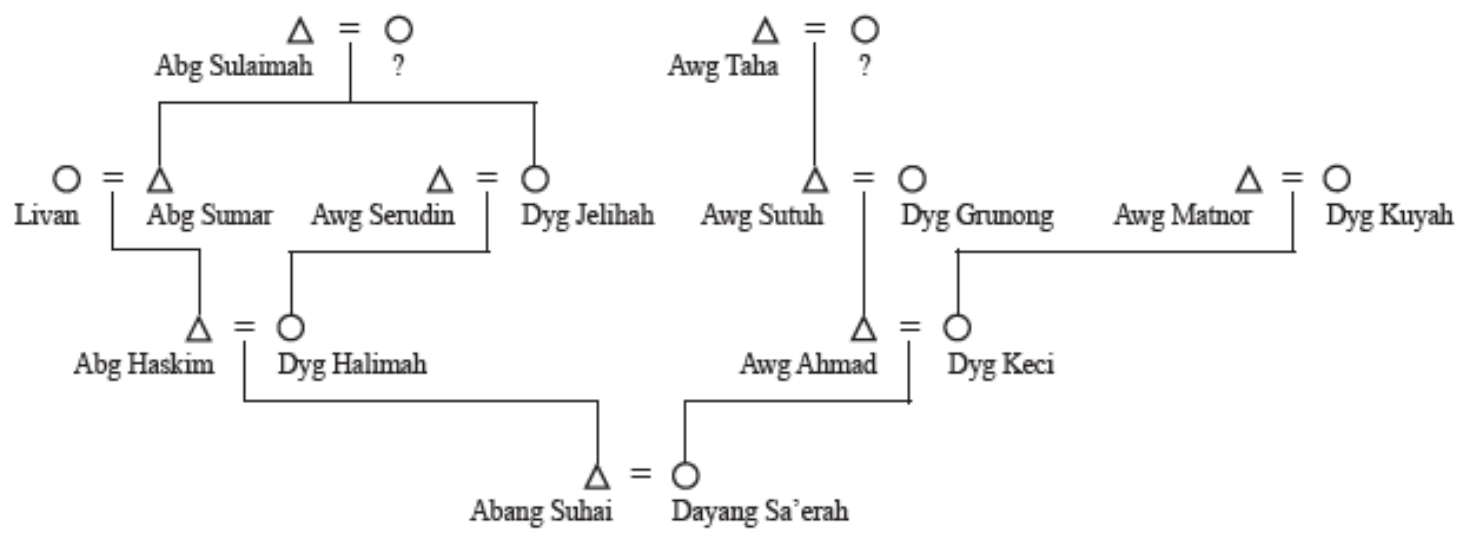

Salasilah 2: Abang Suhai dan Dayang Sa’erah

\section{Pasangan \#3: Awang Radin dan Dayang Jalihah}

Awang Radin merupakan seorang pembantu hospital yang telah bersara dari klinik kesihatan kerajaan di Belaga. Setelah bersara, beliau telah menjadi seorang usahawan dan kontraktor. Beliau mempunyai sebuah restoran dan sebuah rumah di pasar Belaga dan beliau dikenali sebagai usahawan Melayu yang paling berjaya di Belaga.

Awang Radin adalah anak kepada Awang Rajol yang merupakan anak kepada Awang Salleh bin Awang Sulaiman yang berasal dari Burong Pingai. Datuknya dari sebelah bapa, Awang Salleh, telah berkahwin dengan seorang wanita Kayan tempatan yang bernama Ubong Luhat. Ibu Awang Radin yang bernama Dayang Hadjah merupakan anak kepada Abang Sumar bin Abang Sulaiman, yang berasal dari Sadong dan Livan, seorang wanita Kayan dari Batu Kalo.

Keturunan Awang Radin dapat dijejak semula melalui datuknya dari sebelah bapa di Kampung Burong Pingai dan neneknya dari sebelah bapa yang merupakan suku kaum Kayan tempatan. Dari sebelah ibunya, datuknya berasal dari Sadong, manakala neneknya adalah dari Batu Kalo, Belaga. 
Isteri Awang Radin adalah Dayang Jelihah, anak kepada Awang Antek dan Dayang Imah. Awang Antek merupakan anak kepada Awang Matnor dari Kampung Burong Pingai, dan Dayang Kuyuh, seorang wanita Melayu dari Kuching. Dayang Imah merupakan anak kepada Awang Badar bin Awang Tabib dari Kampung Burong Pingai, dan Zainab adalah anak kepada Ibrahim Shah, seorang Melayu yang berasal dari Sumatera dan Aki Urum adalah seorang wanita Punan Bah. Kesimpulannya, datuk nenek Jelihah dari sebelah bapa adalah orang Melayu dari Brunei dan Kuching; datuk dan nenek Jelihah dari sebelah ibu adalah orang Melayu dari Sumatera dan Punan Bah dari Belaga.

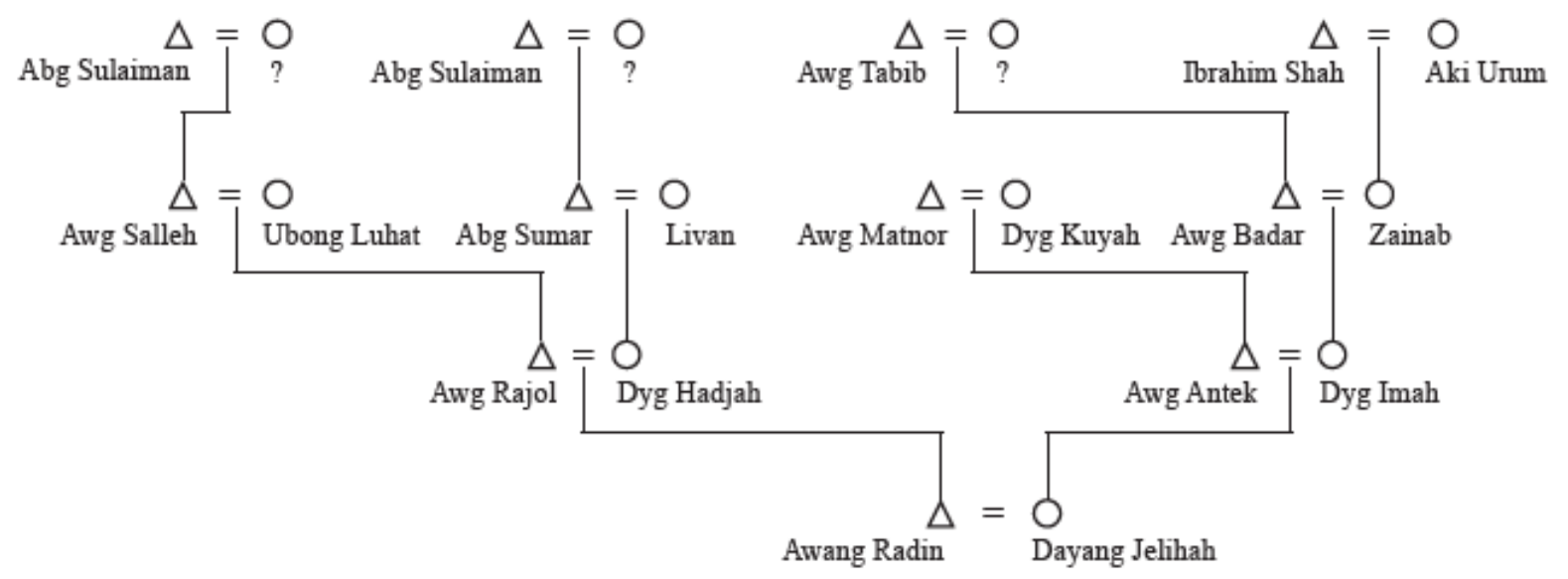

Salasilah 3: Awang Radin dan Dayang Jaliha

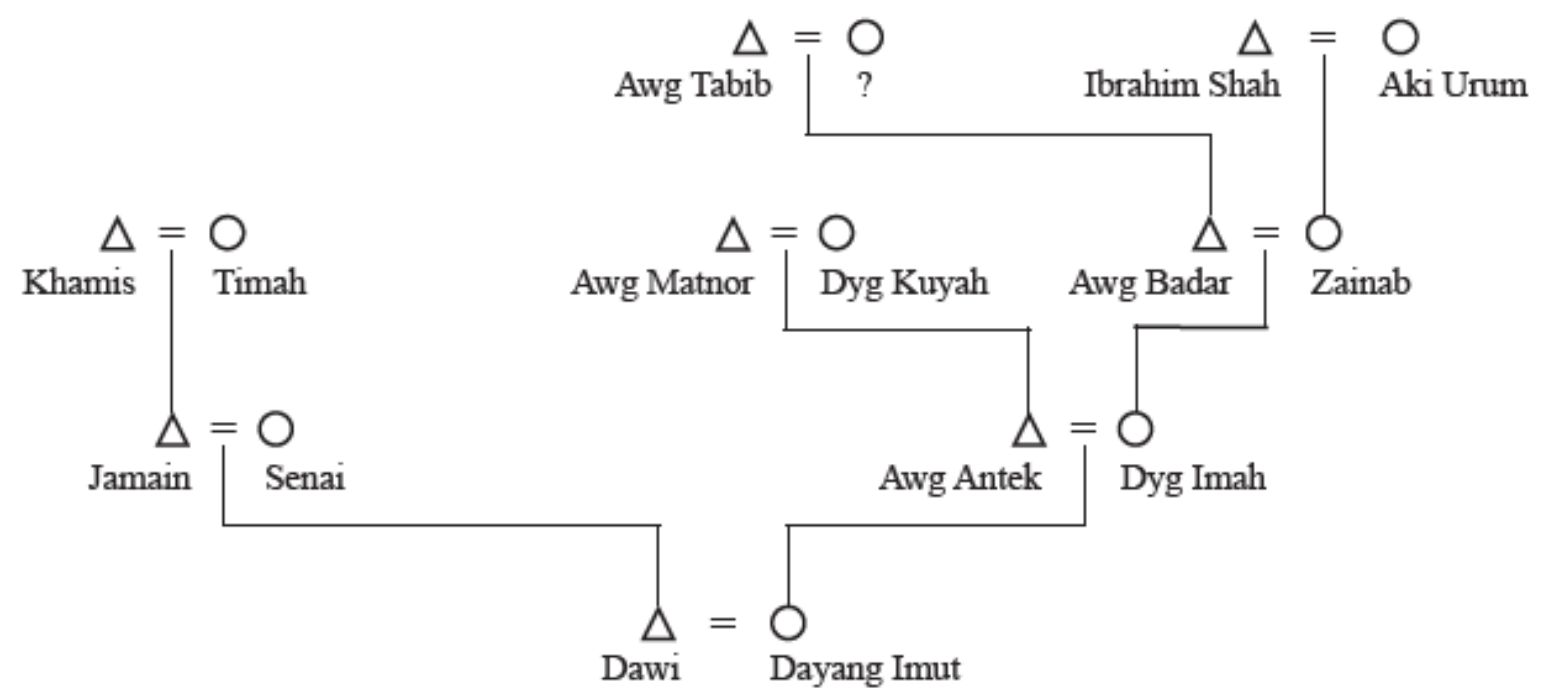

\section{Pasangan \#4: Dawi dan Dayang Imut}

Salasilah 4: Dawi dan Dayang Imut

Dawi merupakan seorang pemandu yang telah bersara dari Jabatan Pertanian di Belaga. Selepas bersara, beliau membantu salah seorang anaknya yang mempunyai restoran di Empangan Hidro Bakun dan juga menjadi kontraktor kecil.

Dawi adalah salah seorang anak kepada Jamain bin Kahmis, seorang Kedayan dari Sibuti di utara Sarawak, dan Senai, seorang wanita Lahanan dari Long Semuang. Datuk Dawi dari sebelah bapa telah berpindah ke Belaga dan berkahwin dengan seorang wanita Sekapan yang bernama Timah selepas dia memeluk agama Islam. Dawi adalah generasi Kedayan yang ketiga menetap di Belaga, dan dia berbangga dengan keturunan Kedayan dan Kajang yang 
diperoleh melalui perkahwinan campur ayahnya dengan wanita Lahanan dan datuk kepada Sekapan.

Isterinya yang bernama Dayang Imut adalah anak kepada Awang Antek dan Dayang Imah. Bapa Dayang Imut adalah anak kepada Awang Matnor dari Kampung Burong Pingai, dan Dayang Kuyah, seorang wanita Melayu yang berasal dari Kuching. Ibu Dayang Imut bernama Dayang Imah merupakan anak kepada Awang Badar bin Awang Tabib di Kampung Burong Pingai, dan Zainab, merupakan anak kepada lelaki Melayu Sumatera dan ibu Punan Bah. Sama dengan adiknya, Dayang Jelihah (rujuk kepada Pasangan \#3), datuk dan nenek Dayang Imut dari sebelah bapa merupakan orang Melayu dari Brunei dan Kuching, dan datuk dan nenek dari sebelah ibu, datuknya ialah orang Sumatera dan neneknya Punan Bah.

\section{Pasangan \#5: Awang Japar dan Edo}

Awang Japar ialah pesara kerajaan. Beliau bekerja sementara sebagai pembantu perubatan di Jabatan Perubatan dan Kesihatan yang berpusat di Belaga, kemudian sebagai kerani di Jabatan Pelajaran sebelum naik pangkat menjadi pentadbir sekolah sehingga pesaraannya pada tahun 2010. Sejurus selepas bersara, dia menjadi bilal untuk surau di Belaga. Dia melepaskan jawatannya sebagai bilal apabila dia dilantik sebagai Tua Kampung di Kampung Melayu, Belaga.

Awang Japar merupakan anak kepada Awang Ahkbar bin Awang Matnor dan Rani binti Khamis. Datuk bapa Awang Japar, Awang Matnor, adalah seorang pedagang Melayu dari Kampung Burong Pingai, Brunei, dan nenek sebelah bapanya merupakan orang dari suku Sekapan, isteri pertama Awang Matnor. Datuk dari sebelah ibunya adalah seorang Kedayan dan nenek dari sebelah ibunya adalah seorang Sekapan. Keturunan Awang Japar dijejak semula ke datuk sebelah ke ayahnya yang merupakan Melayu Brunei, datuk sebelah ibunya yang merupakan seorang Kedayan, dan kedua-dua neneknya merupakan suku kaum Sekapan.

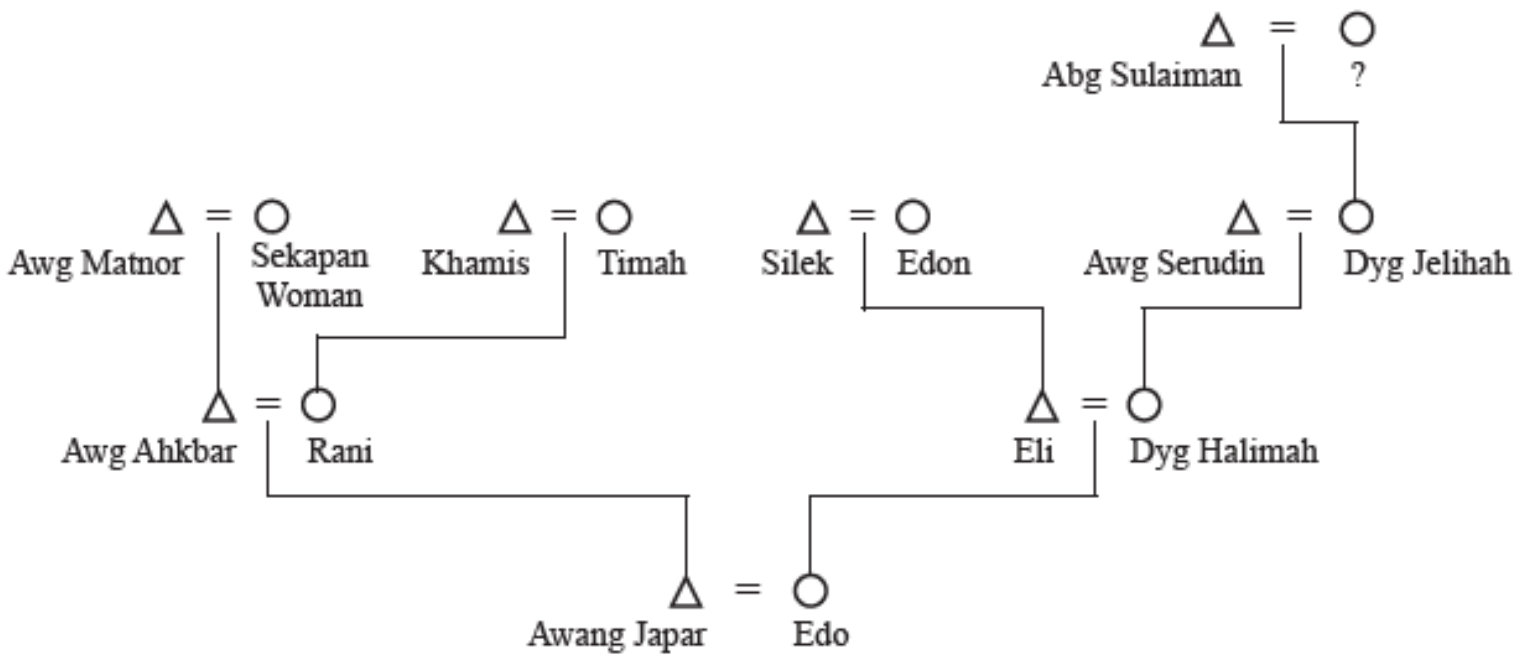

Salasilah 5: Awang Japar dan Edo

Isteri Awang Japar ialah Edo, anak perempuan Eli bin Silek dan Dayang Halimah binti Serudin. Eli, bapa kepada Edo ialah anak lelaki Silek, seorang lelaki Kayan dari Batu Keling, dan Edon, seorang wanita Punan Bah dari Long Bah. Ibunya, Dayang Halimah ialah anak perempuan Awang Serudin, seorang pedagang Melayu dari Kampung Burong Pingai dan Dayang Jelihah binti Abang Sulaiman yang berasal dari Sadong. Keturunan Edo dijejak semula kepada datuk sebelah bapanya yang berketurunan Kayan dan nenek sebelah bapanya pula 
berketurunan Punan Bah; datuk sebelah ibunya berketurunan Melayu Brunei, dan nenek sebelah ibunya berketurunan abang-abang atau perabangan Melayu dari Sadong.

\section{Pasangan \#6 : Dayang Zainab dan Abdul Halim}

Dayang Zainab merupakan anak kepada Awang Ahmad dan Dayang Keci. Ayahnya, Awang Ahmad pula adalah anak kepada Awang Sutuh yang merupakan U.R.A. yang memainkan peranan penting dalam pentadbiran di awal pembentukan daerah Belaga dan ibunya iaitu Dayang Gunong merupakan seorang wanita dari daerah Kanowit ${ }^{31}$. Ibu Dayang Zainab iaitu Dayang Keci merupakan anak kepada Awang Matnor, pedagang Melayu dari kampung Burong Pingai dan pasangannya Dayang Keci, wanita Melayu yang berasal dari Kuching.

Keturunan Dayang Zainab mengaitkannya dengan Kampung Burong Pingai melalui moyangnya dari sebelah bapa iaitu Awang Taha yang merupakan antara pemimpin Melayu terawal di Belaga dan dengan Kanowit melalui nenek dari sebelah bapanya iaitu Dayang Gunong. Dari sebelah ibunya, Dayang Zainab mempunyai kaitan dengan Kampung Burong Pingai melalui datuknya iaitu Awang Matnor. Nenek dari sebelah ibunya pula merupakan seorang wanita Melayu yang berasal dari Kuching.

Dayang Zainab mengahwini Abdul Halim bin Abdullah yang merupakan seorang penjawat awam kanan negeri yang berketurunan Sekapan. Bapa Abdul Halim bernama Tawing Horbat dan ibunya Sedu Agau kedua-duanya berketurunan Sekapan dari Long Dungan.

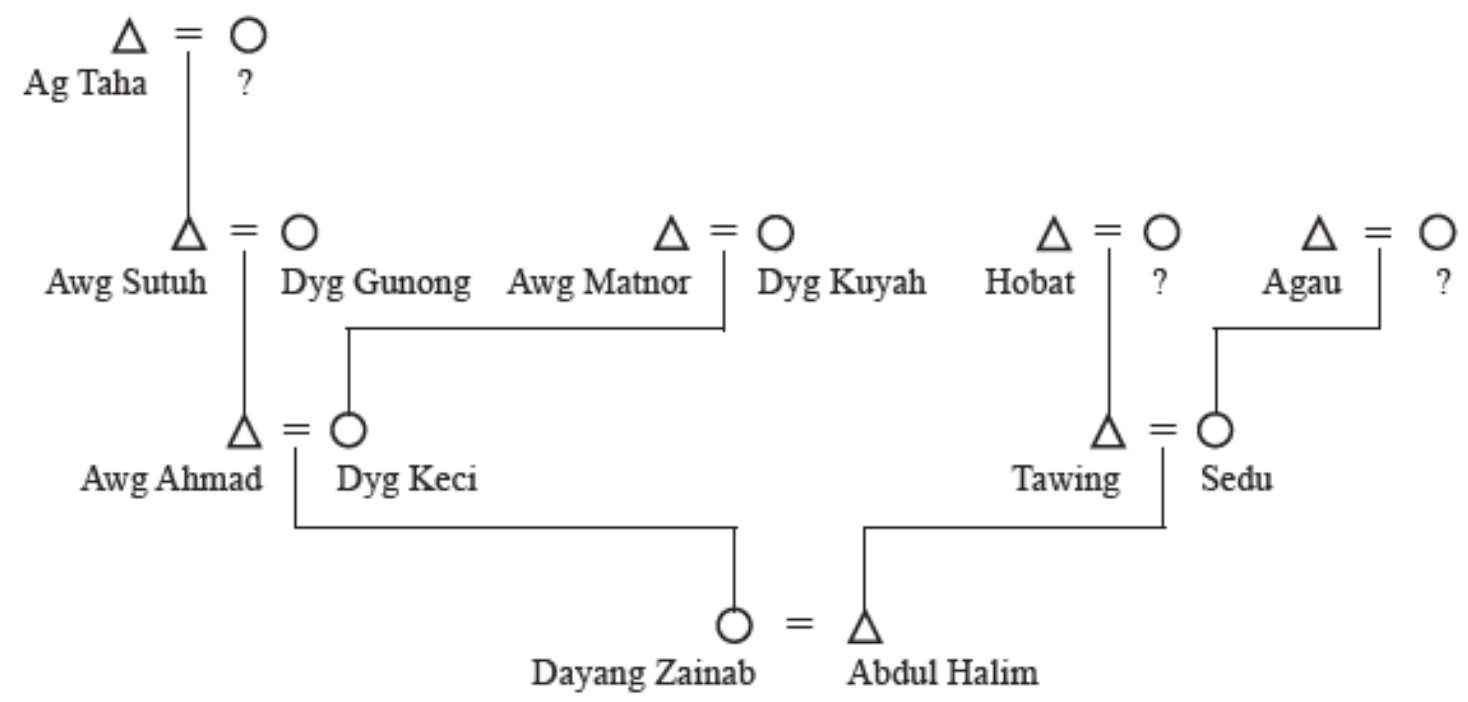

Salasilah 6: Dayang Zainab dan Abdul Halim

\section{Pasangan \#7 : Abang Bujang dan Dayang Jorijan}

Abang Bujang merupakan penjawat awam yang telah bersara. Sebelum itu beliau bertugas di Jabatan Perubatan dan Kesihatan di Belaga dan terlibat dalam projek pembasmian malaria. Kini, beliau merupakan Tua Kampung di Kampung Hijrah, Belaga yang merupakan sebuah kampung yang baru dibuka.

Tidak banyak maklumat yang boleh didapati mengenai salasilah Abang Bujang. Salasilahnya menunjukkan bahawa beliau ialah anak kepada Abang Suhaili, lelaki Melayu dari

\footnotetext{
${ }^{31}$ Kanowit merupakan sekumpulan suku kaum yang terletak di daerah Kanowit. Bahasa dan kebudayaannya mempunyai kaitan dengan Melanau yang tinggal di pesisir dan juga suku kaum Sekapan, Kejaman, Lahanan dan Punan Bah yang mendiami hulu sungai Kajang . Kanowit dari segi bahasa dan budayanya juga mempunyai kaitan kepada masayarakat Tanjong yang berada di daerah Kapit. Kanowit merupakan nama sungai dan daerah.
} 
Kanowit yang pernah bertugas sebagai seorang pemandu di Pejabat Daerah, Kapit. Ibu Abang Suhaili pula merupakan wanita berketurunan Punan Bah yang beragama Islam dan dikenali sebagai Timah Binti Abdullah.

Ibu kepada Abang Bujang ialah Dayang Jorijan yang merupakan anak kepada Awang Rajol dan Dayang Hadjah. Bapa kepada Dayang Jorijan ialah anak kepada Awang Salleh bin Awang Sulaiman, pedagang Melayu dari Kampung Burong Pingai. Ibunya pula ialah Dayang Hadjah yang merupakan anak kepada pasangan Abang Sumar bin Sulaiman seorang lelaki Melayu dari Sadong dan Livan seorang wanita Kayan dari Batu Kalo.

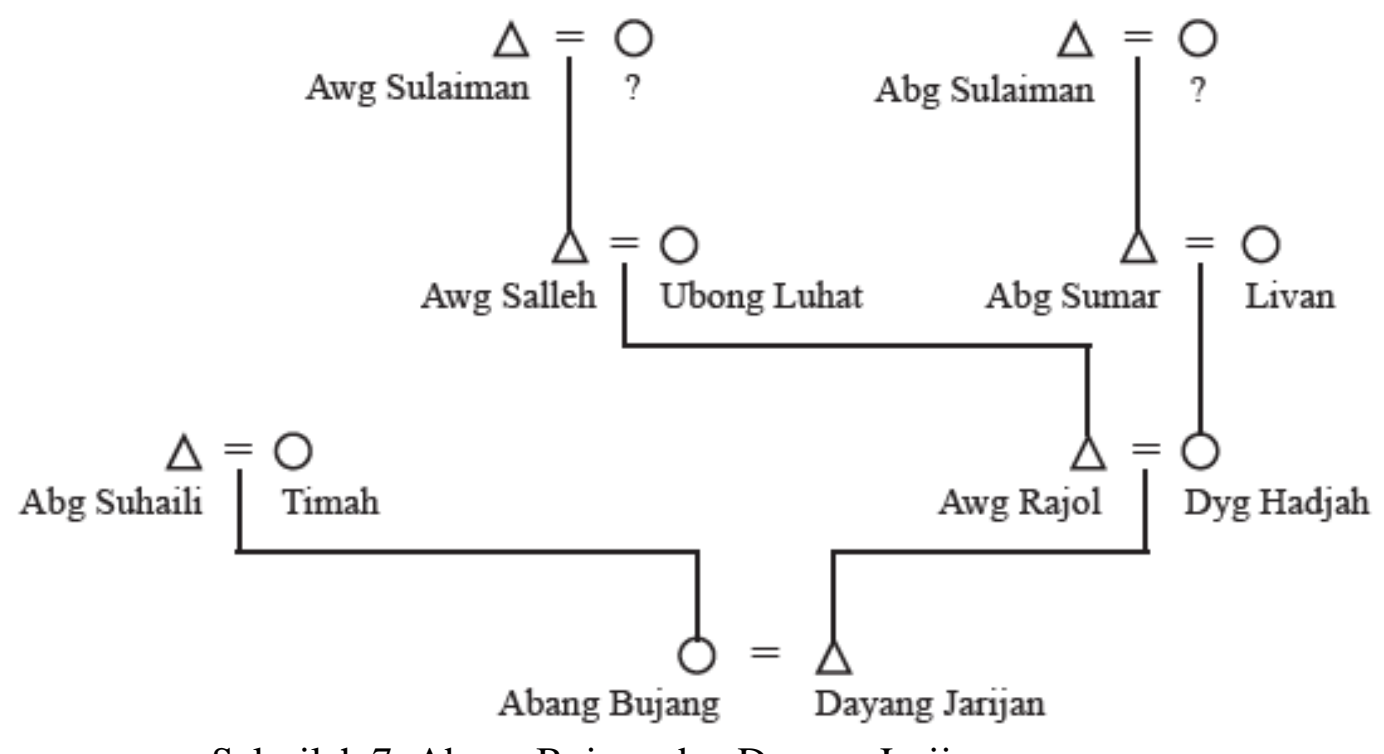

Salasilah 7: Abang Bujang dan Dayang Jorijan

Salasilah ini menunjukkan hubungan antara keluarga di Belaga. Misalnya, keturunan Abang Sulaiman dari Sadong boleh dikesan dalam salasilah 1, 2, 3, 4 dan 7. Keturunan Ibrahim Shah dalam salasilah 1, 3 dan 5. Awang Tabib dalam 1, 4 dan 5 dan keturunan Awang Sulaiman dalam salasilah 3 dan 4. Keturunan Orang Ulu pula iaitu Kayan, Punan Bah, Sekapan dan Lahanan boleh didapati dalam semua salasilah tersebut.

\section{Penutup}

Komuniti Melayu di Belaga sebahagian besarnya terdiri daripada keturunan pedagang Melayu dari Brunei. Mereka datang ke Belaga sekitar abad ke-19 untuk melakukan urusan perdagangan di bawah perlindungan Sultan Brunei memandangkan pada masa tersebut kawasan Belaga berada di bawah naungan kesultanan Brunei. Sebahagian pedagang memilih untuk menetap di Belaga dan ramai dalam kalangan pedagang tersebut mengahwini perempuan tempatan. Pedagang-pedagang ini merupakan pedagang utama di kawasan Hulu Rejang berikutan dengan penubuhan Kubu Vyner dan merupakan kawasan pentadbiran di kuala Belaga dan sungai Balui pada 1884. Ketika kaum Cina perlahan-lahan mendominasi perdagangan selepas tahun 1884, kaum Melayu mula menyesuaikan diri dengan kehidupan biasa di sebuah perkampungan Melayu yang terletak bersebelahan dengan bazar.

Walaupun peranan mereka berkurangan dalam perdagangan selepas tahun 1884, kewujudan Melayu di daerah Belaga tetap penting terutamanya dengan pelantikan pemimpin Melayu tempatan iaitu Awang Sutuh bin Awang Taha yang merupakan U.R.A. yang bertanggungjawab untuk menggalakkan perdagangan dan mengekalkan keamanan dan kestabilan di daerah tersebut. Lebih penting lagi, ketika pedagang Melayu terawal tiba di Belaga, mereka telah mempelajari bahasa tempatan dan boleh menggunakan bahasa tersebut 
dengan fasih serta mereka juga mengahwini wanita tempatan. Kemahiran dalam berbahasa tempatan merapatkan jurang komunikasi dan hubungan sosial dalam kalangan masyarakat, menggalakkan perkahwinan campur, memudahkan penerimaan dan kepercayaan masyarakat tempatan terhadap mereka. Kelebihan ini membolehkan komuniti Melayu yang kecil itu menjadi komponen penting dalam masyarakat yang terasing di hulu sungai ini. 


\section{Rujukan}

Anon. (1884). Rejang, Sarawak Gazette 14(224), 93-95, 1 September 1884.

Abdul Rashid Abdullah. (2000). Sihan Community, paper presented at Workshop Community Profiles of Ethnic Minorities, organized by Centre for Modern Management, Kuching, Sarawak, Malaysia.

Alexander, J. (1989).Culture and ethnic identity: the case of the Lahanan of Ulu Belaga, Sarawak Museum Journal 40 (Special Issue No. 4, Part 1): 51-59.

Alexander, J. (1990). Lahanan social structure: some preliminary considerations, Sarawak Museum Journal 41 (62): 189-212.

Armstrong, R. (1991). People of the same heart: the social world of the Kenyah Badeng. Unpublished PhD thesis: Department of Anthropology, University of Sydney.

Arnold, G. (1956). Prehistory of Usun Apau, Sarawak Museum Journal 7(7): 116-181.

Arnold, G. (1959). Longhouse and jungle: an expedition to Sarawak. London: Chatto \& Windus.

Bamfylde, C. A. (1888a). Rejang monthly report for February 1888, Sarawak Gazette 18(268): 67-68, 1 March 1888.

Bamfylde, C. A. (1888b). Rejang monthly report for March [and] April 1888, Sarawak Gazette 18(269): 74-76, June 1888.

Bamfylde, C. A. (1889a). Rejang monthly report for April and May 1889, Sarawak Gazette 19(282): 101-102, 1 July 1889.

Bamfylde, C. A. (1889b). Rejang monthly report for June 1889” Sarawak Gazette 19(286): 157-159, 1 November 1889.

Bamfylde, C. A. 1890 Rejang monthly report for January 1890, Sarawak Gazette 23(325): 28-29, 1 February 1890.

Bamfylde, C. A. (1892). Rejang monthly report for August 1892, Sarawak Gazette 22(323): 218-219, 1 December 1892.

Baring-Gould, J. (1909). Sibu. Sarawak Gazette 39(529): 157-159.

Brosius, J. P. (1986). River, forest and mountain: the Penan Geng landscape, Sarawak Museum Journal 36(57): 173-184.

Brosius, J. P. (1988). The Penan of Belaga District: considerations for development. [A report submitted to the State Planning Unit]. Kuching: State Planning Unit.

Brosius, J. P. (1990). Penan hunter-gatherers of Sarawak, East Malaysia, AnthroQuest 42: 17. 
Brosius, J. P. (1992a). The axiological presence of death: Penan Geng death names. Unpublished PhD dissertation: Department of Anthropology, University of Michigan, USA.

Brosius, J. P. (1992b). Perspectives in Penan development in Sarawak, Sarawak Gazette 119(1519): 5-22.

Chan, H. (2007). Survival in the rainforest: change and resilience among the Punan Vuhang of Sarawak, East Malaysia. Doctoral dissertation: University of Helsinki, Finland.

Chew, D. (1990). Chinese pioneers on the Sarawak frontier 1841-1941. Singapore: Oxford University Press.

Clayre, I. (1971). The Kajang kingdom: all the Melanau peoples, where do they come from? Sarawak Gazette 97(1362): 120-122.

Clayre, I. (1972). Punan Ba’: Melanau link with the ulu Rejang, Sarawak Gazette 98(1368): 23-25.

Crespigny, C. A. C. de. (1881a). Bintulu. Sarawak Gazette 119175): 40-41, 2 May 1881.

Crespigny, C. A. C. de (1881b). [Mukah] monthly report. Sarawak Gazette 11(178):65-66, 1 August 1881.

Crespigny, C. A. C. de (1881c). Visit to Belaga”, October 7, 1881 Sarawak Gazette 11(180Supplement): 4-7, 7 October 1881.

Crespigny, C. A. C. de. (1882). Journal from Mukah, Sarawak Gazette 12(188): 40-45), 1 June 1882.

Deshon, H.F. (1887). [Kapit] monthly report Sarawak Gazette 17(259): 123-124, 1 July 1887.

District Office, Belaga. (n.d.). Belaga Information Book. [Introduced by John C. B. Fisher, District Officer, Kapit, 14 January 1938, 141 pages].

Ellis, D. B. (1972). A study of the Punan Busang, Sarawak Museum Journal, 20(40-42): 235299.

Gockel, G. (1974). The Long Pekun Sebop, In: Jérôme Rousseau,( ed.), The peoples of central Borneo Sarawak Museum Journal, Special Issue, 22(43): 325-328.

Gueritz, G. (1881a). Bintulu monthly report for March 1881” Sarawak Gazette 11(176): 4849, 1 June 1881.

Gueritz, G. (1881b). Bintulu monthly report for April 1881, Sarawak Gazette 11(176): 49, 1 June 1881.

Gueritz, G. (1882). Bintulu, Sarawak Gazette 12(187), 1 May 1882. 
Guerrerio, A. (1988). Cash crop and subsistence strategies: towards a comparison of Kayan and Lahanan economies, Sarawak Museum Journal 39(60):15-52.

Guerrerio, A. (1992). Some aspects of change among the Baluy Kayan, Sarawak Museum Journal 43(64): 47-105.

Heppel, M. (n.d.). The Bukut [Bhukat] of Long Ayak. Unpublished report submitted to the State Planning Unit, Sarawak.

Kato, Y. (2011). Change and resilience of a hunter-gatherer society in Sarawak, Malaysia: a case study of the Sihan (in Japanese). Ph.D. dissertation, Kyoto University, Japan.

Langub, J. (1975). Distribution of Penan and Punan in Belaga District, Borneo Research Bulletin 7(2): 45-48.

Langub, J. (1988). The Penan strategy (pages 207-208), In Julie Denslow and Christine Padoch (eds.), Peoples of the tropical rain forest. Berkeley: University of California Press.

Langub, J. (2004). Leadership among the Penan of Belaga District in Sarawak, Malaysian Borneo, in A. R. Walker (ed.). Leadership, Justice, and Politics at the grassroots, Contributions to Southeast Asian Ethnography No. 12.

Langub, J. (2009). Notes on the Seping of Belaga Disrict, Sarawak, Borneo Research Bulletin 40: 147-172.

Langub, J. (2016). Fort Vyner and Hugh Brooke Low: The Establishment of an Administrative Centre and Bazaar at the Confluence of the Belaga and Balui Rivers' Sarawak Museum Journal 75(97): 121-155.

Langub, J. \& N. Ishikawa. (2017). Community, river and basin: watersheds in northern Sarawak as a social link, In V. T. King et al, (eds.), Borneo studies in history, society and culture. Singapore: Springer Science + Business Media.

Leach, E.R. (1950). Social science research in Sarawak: a report on the possibilities of a social economic survey of Sarawak presented to the Colonial Social Science Research Council. London: HMSO for the Colonial Office.

Low, H.B. (1882a). Journal of a trip up the Rejang, Sarawak Gazette 12(198): 52-54, 1 July 1882.

Low, H.B. (1882b). Journal of a trip up the Rejang, Sarawak Gazette 12(199): 62-65, 1 August 1882.

Low, H.B. (1882c). Journal of a trip up the Rejang, Sarawak Gazette 12(200): 72-73, 1 September 1882.

Low, H.B. (1882d). Journal of a trip up the Rejang, Sarawak Gazette 12(201): 81-83, 2 October 1882. 
Low, H.B. (1882e). Journal of a trip up the Rejang” Sarawak Gazette 12(202): 93-96. 1 November 1882.

Low, H.B. (1884a). Mr. Low’s November [1883] diary, Sarawak Gazette 14(219): 30-33, 1 April 1884.

Low, H.B. (1884b). Rejang public buildings constructed in Rejang in 18883, Sarawak Gazette 14(220): 39-40, 1 May 1884.

Low, H.B. (1884c). Mr. Low’s December [1883] diary, Sarawak Gazette 14(220): 41-44, 1 May 1884.

Low, H.B. (1884d). Mr. Low’s January [1884] diary, Sarawak Gazette 14(221): 51-55, 2 June 1884.

Low, H.B. (1884e). Mr. Low’s February [1884] diary, Sarawak Gazette 14(222): 71-74, 1 July 1884.

Martinoir, B. de. (1974). Notes on the Kajang, In: Jérôme Rousseau, ed., The peoples of central Borneo, (ed.), Sarawak Museum Journal, Special Issue 22(43): 267-273.

Maxwell, A.R. (1990). Balui reconnaissance: The Badeng Kenyah of Long Gang, Sarawak Museum Journal 41(62): 21-113.

Maxwell, A.R. (1993). Balui reconnaissance: the Sihan of Menamang River, Sarawak Museum Journal 43(64): 1-45.

Maxwell, A.R. (1999). Balui reconnaissance: Notes on the oral history of the Belaga Malay community and early Belaga, Sarawak Museum Journal 54(75): 143-181.

Metcalf, P. (1976). Who are the Berawan? ethnic classification and the distribution of secondary treatment of the dead in central Borneo, Oceania 47: 85-105.

Metcalf, P. (2002). They lie, we lie: getting on with anthropology. London: Routledge.

Metcalf, P. (2010). The life of the longhouse: an archaeology of ethnicity. Cambridge: Cambridge University Press.

Needham, R. (1953). The social organization of the Penan: a Southeast Asia people. DPhil. Thesis: Oxford University.

Needham, R. (1954). Penan and Punan, Journal of the Malayan Branch of the Royal Asiatic Society, (27(1): 173-183.

Needham, R. (1965). Death-names and solidarity in Penan society, Bijdragen tor de Taal- en Volkenkunde 12(1): 58-76.

Nicolaisen, I. (1976). Form and function of Punan Bah ethno-historical tradition, Saraak Museum Journal 24(45): 63-95. 
Nicolaisen, I. (1977/78). The dynamics of ethnic classification: a case study of the Punan Bah in Sarawak, Folk 19-20.

Nicolaisen, I. (1983). Change without development: the transformation of Punan Bah economy, Sarawak Museum Journal 32(53): 191-230.

Nicolaisen, I. (1984). Heritage, identity and cultural policy: the case of Sarawakian burial post, Sarawak Gazette 110(1484)): 3-5.

Nicolaisen, I. (1986). Pride and progress: Kajang response to economic change, Sarawak Museum Journal 36(57): 75-116.

Nicolaisen, I. (1997). Timber, culture and ethnicity: the politicization of ethnic identity, In Robert Winzeler (ed.), Indigenous peoples and the state: politics, land and ethnicity in the Malayan Peninsula and Borneo. New Haven, Connecticut: Monograph 46/Yale Southeast Asia Studies.

Nicolaisen, J.(1976a). The Penan of Sarawak: further notes on the neo-evolutionary concept of hinters, Folk 18:205-236.

Nicolaisen, J. (1976b). The Penan of the Seventh Division of Sarawak: past, present, future, Sarawak Museum Journal 24(45): 35-61.

Nicolaisen, J. (1978). Penan death-names, Sarawak Museum Journal 25(47): 29-41.

Owen, D.A. (1909). Sibu, Sarawak Gazette, 1 April 1909.

Pejabat Daerah Belaga. (2016). Profail Daerah Belaga 2016 [Belaga District Profile]. Mimeograph.

Reece, B. (n.d.). The origins of the Sarawak Abang. Mimeograph.

Rousseau, J. (1974a). The social organization of the Baluy Kayan. Unpublished Ph.D. thesis, Cambridge University, Cambridge.

Rousseau, J. (1974b). The Baluy area, In: Jérôme Rousseau, ed., The peoples of central Borneo. Sarawak Museum Journal Special Issue 22(43): 17-27.

Rousseau, J. (1975). Ethnic identity and social relations in central Borneo, In J. A. Nagata, (ed.), Pluralism in Malaysia: Myth and Reality: A Symposium on Singapore and Malaysia, 32-49. Leiden: Brill.

Rousseau, J. (1990). Central Borneo: ethnic identity and social life in a stratified society. Oxford: Clarendon Press.

Rousseau, J. (1998). Kayan religion: ritual life and religious reform in central Borneo. Leiden: KITLV Press.

Roy, V. (1993). The migration of Kenyah Badeng [Edited with an Introduction by Tan Chee Beng]. Kuala Lumpur: Institute of Advanced Studies, Universiti Malaya. 
St. John, S. (1986). [1862] Life in the forest of the Far East: travels in Sabah and Sarawak in the 1860s. Singapore: Oxford University Press.

Sandin, B. (1983). Notes on the Sian [Sihan] of Belaga” Sarawak Museum Journal 34(55): 67-76.

Seling S. (1974). The flight from the Usun Apau to the headwaters of Tinjar, In Jérôme Rousseau, (ed.), The peoples of central Borneo, Sarawak Museum Journal, Special Issue, 22(43): 331-348.

Strickland, S. (1986). Long term development of Kejaman subsistence: an ecological study, Sarawak Museum Journal 36(57): 117-171.

Strickland, S.(1988). Preliminary notes on a Kejaman-Sekapan oral narrative form, Sarawak Gazette 39(60): 67-75.

Strickland, S. (1989). Kejaman adaptive strategiesin the context of development efforts, Sarawak Museum Journal 40(61) (Part III): 251-270.

Strickland, S. (1995). Materials for the study of Kejaman-Sekapan oral tradition. Sarawak Museum Journal 49(70) (Parts I \& II): 1-637.

Tan Chee Beng. (1993). Introduction: Badeng migration and ethnogenesis, pages xiii-lii, In Vom Roy, The migration of the Kenyah Badeng (edited with an introduction by Tan Chee Beng). Kuala Lumpur: Institute of Advanced Studies, Universiti Malaya.

Thambiah, S. (1995). Culture and adaptation: change among the Bhuket of Sarawak. Ph.D. thesis, The University of Hull, U.K.

Strickland, S. (1951). Some notes on jungle Punan in Kapit district, Sarawak Gazette 5(13): 495-533.

Strickland, S.(1959). Nomadic Punans and Penans, In: Tom Harrisson ed. The peoples of Sarawak. Kuching: Sarawak Museum.

Yao S. (1987). Chinese traders in Belaga town, Sarawak, East Malaysia: geography, indebtedness and appropriation. A final report presented to the Institute of Southeast Asian Studies, Singapore. Mimeograph. 